\title{
Use of estetrol with other steroids for attenuation of neonatal hypoxic-ischemic brain injury: to combine or not to combine?
}

\author{
Ekaterine Tskitishvili' ${ }^{1}$, Christel Pequeux ${ }^{1}$, Carine Munaut ${ }^{1}$, Renaud Viellevoye ${ }^{2}$, \\ Michelle Nisolle ${ }^{3}$, Agnes Noël ${ }^{1}$ and Jean-Michel Foidart ${ }^{1}$ \\ ${ }^{1}$ Laboratory of Development Biology and Tumor, GIGA-Cancer, Department of Obstetrics and Gynecology/Department of \\ Clinical Sciences, University of Liege, Liege 1, Belgium \\ ${ }^{2}$ Neonatal Intensive Care Unit, Department of Pediatrics, University of Liege, Liege 1, Belgium \\ ${ }^{3}$ Department of Obstetrics and Gynecology, University of Liege, Liege1, Belgium \\ Correspondence to: Ekaterine Tskitishvili, email: ekaterinet@hotmail.com \\ Keywords: neonatal hypoxic-ischemic encephalopathy, hippocampus, cortex, estetrol, estradiol, Pathology Section \\ Received: March 16, $2016 \quad$ Accepted: May 17, $2016 \quad$ Published: May 26, 2016
}

\section{ABSTRACT}

Estetrol (E4), estradiol (E2) and progesterone (P4) have important antioxidative and neuroprotective effects in neuronal system. We aimed to study the consequence of combined steroid therapy in neonatal hypoxic-ischemic encephalopathy (HIE). In vitro the effect of E4 combined with other steroids on oxidative stress and the cell viability in primary hippocampal cultures was evaluated by lactate dehydrogenase and cell survival assays. In vivo neuroprotective and therapeutic efficacy of E4 combined with other steroids was studied in HIE model of immature rats. The rat pups rectal temperature, body and brain weights were evaluated. The hippocampus and the cortex were investigated by histo/immunohistochemistry: intact cell number counting, expressions of markers for early gray matter lose, neuro- and angiogenesis were studied. Glial fibrillary acidic protein was evaluated by ELISA in blood samples. In vitro E4 and combinations of high doses of E4 with P4 and/or E2 significantly diminished the LDH activity and upregulated the cell survival. In vivo pretreatment or treatment by different combinations of E4 with other steroids had unalike effects on body and brain weight, neuro- and angiogenesis, and GFAP expression in blood. The combined use of E4 with other steroids has no benefit over the single use of E4.

\section{INTRODUCTION}

Neonatal Hypoxic-ischemic Encephalopathy (HIE) is one of the primary reasons of severe impairment or death among preterm, near-term and term neonates. The most recent investigation is posing the speculation that neonatal HIE might start antenatally, implying importance of different factors (i.e. genetic and/or infectious, and placental factors), but parturition might have importance for the final development of HIE [1]. As a consequence, brain hypoxia along with ischemia and the reduced cerebral blood flow (CBF) might lead to perinatal HIE $[2,3]$. The most vulnerable areas of the immature brain are: the cornu ammonis (CA1, CA3 and CA4) regions of the hippocampus, the cerebellum, layers III, V and VI of the neocortex and the neostriatum [4]. At cellular level different pathological cascades can directly contribute to long-term apoptosis in distal neuronal structures: oxidative stress, peroxynitrite-induced neurotoxicity, lipid peroxidation, mitochondrial and DNA damage [57]. Inflammatory mediators also have importance in the pathogenesis of HIE: NF-kB activation in neurons could provide survival, whereas activation in glial cells enhances neuronal cell death [8]. Inflammation may modulate vulnerability to brain damage and development of this pathological condition by representing a possible final common pathway of brain injury [9].

According to recent investigations, mortality and the neurodevelopmental outcomes in infants with moderate and severe HIE are tremendous: from 23 to $27 \%$ of infants die prior to discharge from the Neonatal Intensive Care unit (NICU), whereas from 37 to $38 \%$ die at follow up 18-22 months later [10, 11]. Among survivors, the neurodevelopmental outcome at 18 months might include: 
mental and psychomotor development retardation, cerebral palsy, epilepsy, blindness and hearing impairment $[10,11]$ though mild encephalopathy might result in understated changes in neurodevelopment later in life [12]. Different preclinical and clinical studies proposed several treatment possibilities for attenuation of HIE. Nowadays therapeutic hypothermia became the only strategy for treatment of HIE at term, and the rate of death or severe disability in infants with HIE is decreased from $60 \%$ to $46 \%$ after cooling [13].

Recent investigations already proved the neuroprotective efficacy of Estradiol (E2) and Progesterone (pregn-4-ene-3,20-dione) (P4) in different experimental models and clinical studies of neurological diseases: Parkinson's and Alzheimer's diseases, ischemic stroke, spinal cord injury, traumatic brain injury (TBI) and multiple sclerosis [14-25]. It was demonstrated that tremendous effect of $\mathrm{P} 4$ depends on attenuation of oxidative injury resulting from glutamate and glucose deprivation-induced toxicity [26-29]. It also protects against FeSO4 and amyloid $\beta$-peptide-induced toxicity in vitro in primary hippocampal cultures $[30,31]$.

E4 is a major E2 metabolite detected in maternal urine about 9 weeks of gestation, substantially increasing during pregnancy [32]. Our recent studies showed that E4 has very good antioxidant, neuroprotective, neuro- and angiogenic properties [33]. It was also shown that this steroid modulates the production of allopregnanolone in various brain regions, and upregulates expression of $\beta$-endorphin in the nervous system $[34,35]$. E4 acts as selective estrogen receptor modulator (SERM) that activates the nuclear estrogen receptor $\alpha(E R \alpha)$, but inhibits its membrane form. As a consequence, E4 has biological activities distinct from E2, depending on the tissues and cells, and the selective binding to the nuclear/membrane form of ER $\alpha$ [36]. Only limited data show the significance of separately used estrogens and progesterone in attenuation of neonatal hypoxic-ischemic encephalopathy [33, 37-41] based on a model of HIE in a 7-day-old immature rats [42].

Postnatal E2 and P4 combined replacement in extremely preterm infants demonstrated reduction of the risk for cerebral palsy, spasticity, and ametropia at 5 years neurodevelopmental follow-up [43]. Several studies have suggested that P4 does not affect the positive effects of E2 [28, 44, 45], whereas others proposed that P4 might antagonize the positive effects of E2 [46-51].

Studies on neuroprotective properties of combined use of E4 with other steroids have not been performed so far. We aimed to study the possible effect of E4 with P4 and/or E2 for attenuation of neonatal HIE and define whether the combined use of E4 with other steroids might have any advantage over the single use of E4.

\section{RESULTS}

\section{Effect of combined treatment of E4 alone or with E2 and/or P4 on H202-induced LDH activity and cell survival}

The treatment effect of E4 alone or combined with E2 and/or P4 on oxidative stress was studied in primary hippocampal cell cultures at 7 day in vitro (DIV). Cultures were exposed either to $650 \mu \mathrm{M}, 3.25 \mathrm{mM}$ and $6.5 \mathrm{mM} \mathrm{E} 4$ alone or to combination of E4 with 100nM E2 and/or $1 \mathrm{mM} P 4$ by $1 \mathrm{~h}$ after stimulation with $100 \mu \mathrm{M}$ of $\mathrm{H} 202$. As shown in (Figure 1A, 1B), LDH activity was significantly downregulated in all the study groups compared to the H202-treated group. The LDH activity level was significantly lower in cultures combinedly treated by different concentrations of E4 with E2 and P4 than in cultures treated by E4 alone (Figure 1A, 1B). Similar pattern of LDH activity was observed in cultures treated either by $6.5 \mathrm{mM}$ E4 with E2 (Figure $1 \mathrm{~A}$ ) or by different concentrations of E4 with P4 (Figure 1B) compared to cultures treated by E4 alone.

The cell survival rate was significantly increased in cultures treated either by $6.5 \mathrm{mM}$ E4 with/without E2 (Figure 1C) or by $6.5 \mathrm{mM} \mathrm{E} 4$ with/without P4 (Figure 1D) or by high doses of E4 with E2 and P4 (Figure 1C, 1D) than in H202-treated cultures. Furthermore, cells exposed to $6.5 \mathrm{mM}$ E4 with/without E2 had significantly higher cell survival rate than the cultures treated by $650 \mu \mathrm{M} \mathrm{E} 4$ with/without E2 (Figure 1C), though the dose-dependent pattern was more prominent when different concentrations of E4 were used with/without P4 (Figure 1D). Cells treated by $6.5 \mathrm{mM}$ E4 and P4 had significantly higher survival rate than the cells treated by E4 alone (Figure 1D). Cell cultures combinedly treated by $6.5 \mathrm{mM}$ E4 with E2 and P4 had significantly higher survival level than the cells treated either by $6.5 \mathrm{mM} \mathrm{E} 4$ with/without E2 (Figure 1C) or by the lower doses of E4 combined with E2 and P4 (Figure 1C, 1D).

\section{Rat pups rectal temperature}

Brain injury raises body temperature and the raised temperature is a marker for an underlying process with encephalopathy [52]. In neuroprotective model, immediately after hypoxic-ischemic (HI) insult (at $0 \mathrm{~h}$ time point), the rectal temperature was significantly increased only in animals from the vehicle group compared to the sham group, whereas $2 \mathrm{~h}$ later the rectal temperature was significantly decreased in groups pretreated by combination of $5 \mathrm{mg} / \mathrm{kg} / \mathrm{d}$ E4 and $1.6 \mathrm{mg} / \mathrm{kg} / \mathrm{d} \mathrm{P} 4$ with/ without $136 \mathrm{ng} / \mathrm{kg} / \mathrm{d}$ E2 compared to the sham group, though $4 \mathrm{~h}$ later no significant differences were observed among the study groups (Figure 2A). 
Table 1: Body and Brain weights of rat pups from study groups.

\begin{tabular}{|c|c|c|c|c|}
\hline Groups & Body & Weight (g) & Brain & $\boldsymbol{P}$ \\
\hline & P7 & P14 & weight (g) & \\
\hline \multicolumn{5}{|l|}{ Pretreatment } \\
\hline Sham & $12.04 \pm 0.52$ & $26.96 \pm 0.73$ & $1.20 \pm 0.01$ & \\
\hline Vehicle & $12.52 \pm 0.41$ & $27.86 \pm 0.65$ & $1.15 \pm 0.01$ & \\
\hline $5 \mathrm{mg} / \mathrm{kg} \mathrm{E4}$ & $15.03 \pm 0.68$ & $24.61 \pm 1.19$ & $1.18 \pm 0.03$ & \\
\hline $5 \mathrm{mg} / \mathrm{kg} \mathrm{E4}+1.6 \mathrm{mg} / \mathrm{kg} \mathrm{P4}$ & $12.89 \pm 0.46$ & $26.63 \pm 1.30$ & $1.21 \pm 0.03$ & \\
\hline $5 \mathrm{mg} / \mathrm{kg} \mathrm{E4}+1.6 \mathrm{mg} / \mathrm{kg} \mathrm{P4}+136 \mathrm{ng} / \mathrm{kg} \mathrm{E2}$ & $11.93 \pm 0.36$ & $22.04 \pm 0.66$ & $1.19 \pm 0.03$ & \\
\hline $5 \mathrm{mg} / \mathrm{kg} \mathrm{E4+16mg/kg} \mathrm{P4}$ & $15.94 \pm 0.29$ & $25.58 \pm 1.47$ & $1.17 \pm 0.02$ & $*$ \\
\hline $5 \mathrm{mg} / \mathrm{kg} \mathrm{E4}+16 \mathrm{mg} / \mathrm{kg} \mathrm{P4+136ng/kg} \mathrm{E2}$ & $14.27 \pm 0.70$ & $21.55 \pm 0.68$ & $1.16 \pm 0.03$ & \\
\hline $5 \mathrm{mg} / \mathrm{kg} \mathrm{E4+136ng/kg} \mathrm{E2}$ & $11.94 \pm 0.59$ & $23.91 \pm 1.34$ & $1.12 \pm 0.03$ & \\
\hline $10 \mathrm{mg} / \mathrm{kg} \mathrm{E4}$ & $13.35 \pm 0.47$ & $27.10 \pm 0.83$ & $1.19 \pm 0.02$ & \\
\hline $10 \mathrm{mg} / \mathrm{kg} \mathrm{E} 4+1.6 \mathrm{mg} / \mathrm{kg} \mathrm{P4}$ & $12.83 \pm 0.66$ & $25.57 \pm 0.99$ & $1.25 \pm 0.01$ & \\
\hline $10 \mathrm{mg} / \mathrm{kg} \mathrm{E} 4+1.6 \mathrm{mg} / \mathrm{kg} \mathrm{P} 4+136 \mathrm{ng} / \mathrm{kg} \mathrm{E2}$ & $13.59 \pm 0.50$ & $27.91 \pm 1.18$ & $1.23 \pm 0.02$ & \\
\hline $10 \mathrm{mg} / \mathrm{kg} \mathrm{E4}+16 \mathrm{mg} / \mathrm{kg} \mathrm{P4}$ & $13.55 \pm 0.34$ & $26.46 \pm 1.20$ & $1.23 \pm 0.03$ & \\
\hline $10 \mathrm{mg} / \mathrm{kg} \mathrm{E4+16mg/kg} \mathrm{P4+136ng/kg} \mathrm{E2}$ & $13.15 \pm 0.25$ & $27.99 \pm 1.03$ & $1.24 \pm 0.01$ & \\
\hline $10 \mathrm{mg} / \mathrm{kg} \mathrm{E4+136ng/kg} \mathrm{E2}$ & $12.47 \pm 0.52$ & $25.69 \pm 0.93$ & $1.21 \pm 0.03$ & \\
\hline \multicolumn{5}{|l|}{ Treatment } \\
\hline Sham & $12.04 \pm 0.52$ & $26.96 \pm 0.73$ & $1.20 \pm 0.01$ & \\
\hline Vehicle & $13.43 \pm 0.35$ & $26.63 \pm 0.71$ & $1.17 \pm 0.02$ & \\
\hline $5 m g / k g E 4$ & $14.14 \pm 0.62$ & $28.21 \pm 1.23$ & $1.28 \pm 0.01$ & \\
\hline $5 \mathrm{mg} / \mathrm{kg} \mathrm{E4}+1.6 \mathrm{mg} / \mathrm{kg} \mathrm{P4}$ & $14.08 \pm 0.65$ & $27.16 \pm 0.66$ & $1.23 \pm 0.02$ & \\
\hline $5 \mathrm{mg} / \mathrm{kg} \mathrm{E4+1.6mg/kg} \mathrm{P4+136ng/kg} \mathrm{E2}$ & $13.66 \pm 0.43$ & $25.67 \pm 0.88$ & $1.29 \pm 0.01$ & \\
\hline $5 \mathrm{mg} / \mathrm{kg} \mathrm{E4}+16 \mathrm{mg} / \mathrm{kg} \mathrm{P4}$ & $13.51 \pm 0.41$ & $27.11 \pm 1.18$ & $1.26 \pm 0.03$ & \\
\hline $5 \mathrm{mg} / \mathrm{kg} \mathrm{E4}+16 \mathrm{mg} / \mathrm{kg} \mathrm{P4+136ng/kg} \mathrm{E2}$ & $15.03 \pm 0.49$ & $28.13 \pm 1.37$ & $1.22 \pm 0.03$ & \\
\hline $5 \mathrm{mg} / \mathrm{kg} \mathrm{E4+136ng/kg} \mathrm{E2}$ & $13.93 \pm 0.37$ & $24.43 \pm 2.07$ & $1.15 \pm 0.05$ & \\
\hline $10 \mathrm{mg} / \mathrm{kg} \mathrm{E4}$ & $14.25 \pm 0.59$ & $30.82 \pm 0.54$ & $1.34 \pm 0.01$ & ** \\
\hline $10 \mathrm{mg} / \mathrm{kg} \mathrm{E} 4+1.6 \mathrm{mg} / \mathrm{kg} \mathrm{P4}$ & $13.83 \pm 0.66$ & $24.97 \pm 0.89$ & $1.20 \pm 0.02$ & \\
\hline $10 \mathrm{mg} / \mathrm{kg} \mathrm{E} 4+1.6 \mathrm{mg} / \mathrm{kg} \mathrm{P4+136ng/kg} \mathrm{E2}$ & $13.44 \pm 0.47$ & $25.48 \pm 1.22$ & $1.25 \pm 0.02$ & \\
\hline $10 \mathrm{mg} / \mathrm{kg} \mathrm{E} 4+16 \mathrm{mg} / \mathrm{kg} \mathrm{P4}$ & $13.93 \pm 0.39$ & $25.98 \pm 0.74$ & $1.32 \pm 0.01$ & \\
\hline 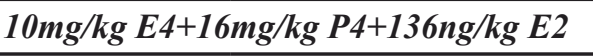 & $14.17 \pm 0.51$ & $32.41 \pm 0.96$ & $1.26 \pm 0.02$ & \\
\hline $10 \mathrm{mg} / \mathrm{kg} \mathrm{E} 4+136 \mathrm{ng} / \mathrm{kg} \mathrm{E2}$ & $15.04 \pm 0.42$ & $28.64 \pm 2.76$ & $1.22 \pm 0.04$ & \\
\hline
\end{tabular}

Significant differences were observed: * Body weight at P7- $5 \mathrm{mg} / \mathrm{kg} / \mathrm{d}$ E4 $+16 \mathrm{mg} / \mathrm{kg} / \mathrm{d}$ P4 group vs. sham, vehicle and $5 \mathrm{mg} /$ $\mathrm{kg} / \mathrm{d} \mathrm{E} 4+136 \mathrm{ng} / \mathrm{kg} / \mathrm{d}$ E2 in pretreated groups; ** Brain weight- $10 \mathrm{mg} / \mathrm{kg} / \mathrm{d}$ E4 vs. vehicle in treated groups.

In therapeutic model, between the study groups immediately after $\mathrm{HI}$ insult no significant differences were detected, whereas $2 \mathrm{~h}$ later groups treated by combination of any dose of E4 with $16 \mathrm{mg} / \mathrm{kg} /$ day P4 plus $136 \mathrm{ng} / \mathrm{kg} / \mathrm{d}$ E2 had significantly decreased rectal temperature than the vehicle group or the groups treated by the same doses of $\mathrm{E} 4$ with $1.6 \mathrm{mg} / \mathrm{kg} / \mathrm{d} \mathrm{P} 4$ and E2. Moreover, combination of $10 \mathrm{mg} / \mathrm{kg} / \mathrm{d}$ E4 with $16 \mathrm{mg} / \mathrm{kg} / \mathrm{d}$ P4 and $136 \mathrm{ng} / \mathrm{kg} / \mathrm{d}$ E2 significantly downregulated the rectal temperature compared to the sham group, or the group treated by the same doses of E4 and P4 (Figure 2B). Also, the groups treated by $10 \mathrm{mg} / \mathrm{kg} / \mathrm{d} \mathrm{E} 4$ alone or combined with $1.6 \mathrm{mg} /$ $\mathrm{kg} / \mathrm{d} \mathrm{P} 4$ had significantly decreased rectal temperature compared to the group treated by the same doses of E4 and $\mathrm{P} 4$ along with E2. At $4 \mathrm{~h}$ after $\mathrm{HI}$ event, animals treated by E4 and E2 with/without $16 \mathrm{mg} / \mathrm{kg} / \mathrm{d}$ P4 had significantly decreased rectal temperature along with the sham group compared to animals treated by single doses of E4 (Figure 2B). The same pattern was observed between groups treated by $10 \mathrm{mg} / \mathrm{kg} / \mathrm{d} \mathrm{E} 4$ with $1.6 \mathrm{mg} / \mathrm{kg} / \mathrm{d} \mathrm{P} 4$ and E2, and 
the group treated by E4 alone. Treatment by $5 \mathrm{mg} / \mathrm{kg} / \mathrm{d}$ E4 with $16 \mathrm{mg} / \mathrm{kg} / \mathrm{d} \mathrm{P} 4$ and E2 significantly decreased the rectal temperature than the treatment by the same combination of compounds with $1.6 \mathrm{mg} / \mathrm{kg} / \mathrm{d}$ P4 (Figure 2B).

\section{Body and brain weight evaluation}

Table 1 demonstrates that animals pretreated for 4 consecutive days by combination of $5 \mathrm{mg} / \mathrm{kg} / \mathrm{d}$ E4 and $16 \mathrm{mg} / \mathrm{kg} / \mathrm{d}$ P4 at postnatal day 7 (P7) had significantly higher weight than animals from the vehicle, sham and combinedly pretreated by $5 \mathrm{mg} / \mathrm{kg} / \mathrm{d} \mathrm{E} 4$ and E2 groups. Brain-body weight ratio was significantly higher in groups pretreated by $5 \mathrm{mg} / \mathrm{kg} / \mathrm{d}$ E4 plus $136 \mathrm{ng} / \mathrm{kg} / \mathrm{d}$ E2 in combination either with $1.6 \mathrm{mg} / \mathrm{kg} / \mathrm{d}(0,054 \pm 0.001)$ or $16 \mathrm{mg} / \mathrm{kg} / \mathrm{d}$ P4 $(0,054 \pm 0.001)$ than in the vehicles $(0.042 \pm$ $0.001)$. In treated groups only animals from $10 \mathrm{mg} / \mathrm{kg} / \mathrm{d} \mathrm{E} 4$ group had significantly higher brain weight compared to the vehicles (Table 1) though the brain-body weight ratio was not significantly different between the study groups (data not shown).

\section{(A)}

(B)

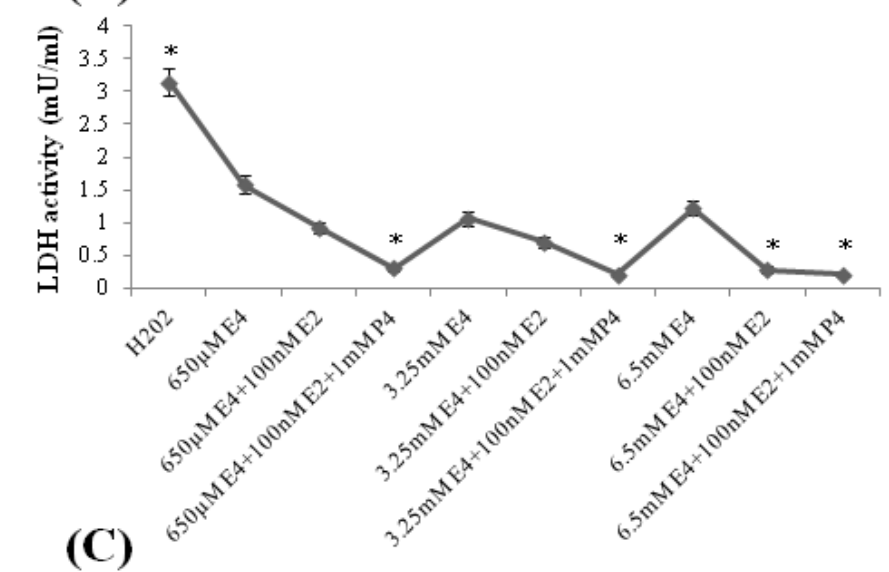

(D)
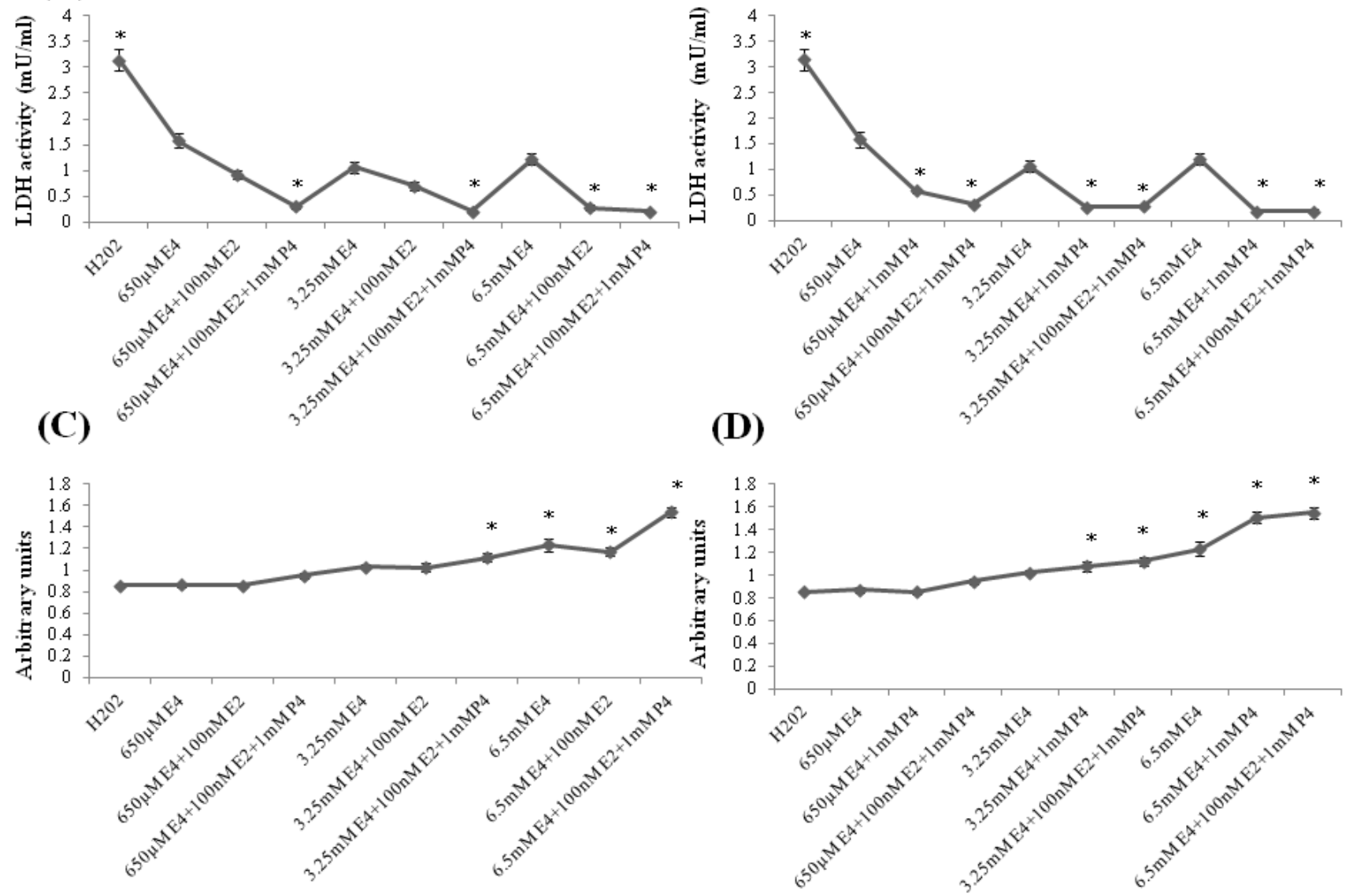

Figure 1: Effect of E4 alone or in combination with $\mathrm{P} 4$ and/or E2 on LDH activity and cell viability in primary hippocampal cell cultures subjected to the H202-induced oxidative stress. A.-D. Primary hippocampal neuronal cells were treated with $650 \mu \mathrm{M}, 3.25 \mathrm{mM}$ and $6.5 \mathrm{mM}$ of estetrol alone or in combination with $100 \mathrm{nM}$ E2 and/or $1 \mathrm{mM}$ P4 for $1 \mathrm{~h}$ after induction of oxidative stress by $100 \mu \mathrm{M}$ of $\mathrm{H} 202$ for $30 \mathrm{~min}$. A.-B. LDH activity was significantly downregulated in all the study groups compared to the H202-treated group. The LDH activity level was significantly lower in cultures treated either with $6.5 \mathrm{mM} \mathrm{E4} \mathrm{and} \mathrm{100nM} \mathrm{E2} \mathrm{(A)} \mathrm{or} \mathrm{in}$ cultures treated by any dose of E4 along with $1 \mathrm{mM}$ P4 than in cultures treated by E4 alone (B) as well as in cultures combinedly treated by any dose of E4 along with 1mM P4 and 100nM E2 than in cultures treated by E4 alone (A-B). C. Cell survival was significantly upregulated in cell cultures treated either by $6.5 \mathrm{mM} \mathrm{E} 4$ with/without $100 \mathrm{nM}$ E2 or by $3.25 \mathrm{mM}, 6.5 \mathrm{mM}$ E4 with $100 \mathrm{nM} \mathrm{E} 2$ and $1 \mathrm{mM}$ P4 than in H202treated cultures. Cells exposed to $6.5 \mathrm{mM} \mathrm{E4}$ with/without 100nM E2 had significantly higher cell survival rate than the cultures treated by $650 \mu \mathrm{M}$ E4 with/without $100 \mathrm{nM}$ E2. Cells combinedly treated by $6.5 \mathrm{mM}$ E4 with $100 \mathrm{nM}$ E2 and $1 \mathrm{mM}$ P4 had significantly higher survival level than the cells treated by $6.5 \mathrm{mM} \mathrm{E} 4 \mathrm{with} /$ without $100 \mathrm{nM}$ E2. D. Cell survival was significantly upregulated in cultures treated by $6.5 \mathrm{mM}$ E4 with/without $1 \mathrm{mM}$ P4 or by $3.25 \mathrm{mM}, 6.5 \mathrm{mM} \mathrm{E} 4$ with $100 \mathrm{nM}$ E2 and $1 \mathrm{mM}$ P4 than in H202-treated cultures. The dosedependent pattern was observed when $650 \mu \mathrm{M}, 3.25 \mathrm{mM}$ and $6.5 \mathrm{mM}$ E4 were used with/without $1 \mathrm{mM}$ P4. (C-D) Cell cultures combinedly treated by $6.5 \mathrm{mM} \mathrm{E} 4$ with $100 \mathrm{nM}$ E2 and $1 \mathrm{mM}$ P4 had significantly higher survival level than the cells treated by $650 \mu \mathrm{M}, 3.25 \mathrm{mM}$ E4 in combination with $100 \mathrm{nM}$ E2 and $1 \mathrm{mM} \mathrm{P} 4$. All measurements are expressed as mean \pm SEM.* $p \leq 0.05$. 
Table 2: Intact cell counting/per visual field in the hippocampus and cortex in hematoxylin-eosin stained sections.

\begin{tabular}{|c|c|c|c|c|c|}
\hline Groups & DG & SGZ & CA1 & CA2/CA3 & Cortex \\
\hline \multicolumn{6}{|l|}{ Pretreatment } \\
\hline Sham & $202.70 \pm 18.28 *$ & $89.80 \pm 8.57 \S \S \S$ & $55.40 \pm 3.34$ & $44.70 \pm 2.38$ & $47.20 \pm 3.90$ \\
\hline Vehicle & $76.30 \pm 10.23 * *$ & $33.20 \pm 5.22 \#$ & $48.30 \pm 6.65$ & $33.80 \pm 3.93$ & $33.30 \pm 3.24$ \\
\hline $5 m g / k g ~ E 4$ & $183.40 \pm 11.96$ & $72.10 \pm 5.93$ & $48.60 \pm 2.57$ & $51.80 \pm 3.56$ & $39.80 \pm 2.74$ \\
\hline $5 \mathrm{mg} / \mathrm{kg} \mathrm{E4}+1.6 \mathrm{mg} / \mathrm{kg} \mathrm{P4}$ & $168.80 \pm 17.52$ & $62.50 \pm 6.97$ & $54.00 \pm 3.11$ & $45.30 \pm 2.89$ & $36.50 \pm 3.19$ \\
\hline $5 \mathrm{mg} / \mathrm{kg} \mathrm{E4+1.6mg/kg} \mathrm{P4+136ng/kg} \mathrm{E2}$ & $168.80 \pm 4.71$ & $67.7 \pm 3.32$ & $53.60 \pm 3.47$ & $40.80 \pm 3.06$ & $43.60 \pm 4.02$ \\
\hline $5 \mathrm{mg} / \mathrm{kg} \mathrm{E4+16mg/kg} \mathrm{P4}$ & $148.60 \pm 12.97$ & $68.60 \pm 5.15$ & $51.70 \pm 5.69$ & $54.60 \pm 7.00$ & $41.90 \pm 4.51$ \\
\hline $5 \mathrm{mg} / \mathrm{kg} \mathrm{E4+16mg/kg} \mathrm{P4+136ng/kg} \mathrm{E2}$ & $167.40 \pm 13.96$ & $73.90 \pm 7.96$ & $45.00 \pm 6.07$ & $44.40 \pm 6.59$ & $40.20 \pm 3.60$ \\
\hline $5 m g / k g E 4+136 n g / k g ~ E 2$ & $111.40 \pm 6.69$ & $42.90 \pm 3.09$ & $56.20 \pm 3.76$ & $38.50 \pm 2.85$ & $36.50 \pm 3.37$ \\
\hline $10 \mathrm{mg} / \mathrm{kg} \mathrm{E4}$ & $227.30 \pm 14.18 * * *$ & $86.10 \pm 5.84$ & $64.90 \pm 3.63$ & $42.40 \pm 2.49$ & $39.60 \pm 2.86$ \\
\hline $10 \mathrm{mg} / \mathrm{kg} \mathrm{E} 4+1.6 \mathrm{mg} / \mathrm{kg} \mathrm{P4}$ & $166.90 \pm 11.97$ & $64.30 \pm 5.26$ & $58.30 \pm 3.53$ & $45.30 \pm 2.92$ & $45.40 \pm 5.70$ \\
\hline $10 \mathrm{mg} / \mathrm{kg} \mathrm{E} 4+1.6 \mathrm{mg} / \mathrm{kg} \mathrm{P4}+136 \mathrm{ng} / \mathrm{kg} \mathrm{E2}$ & $123.4 \pm 7.25$ & $54.20 \pm 4.84$ & $65.90 \pm 4.91$ & $46.10 \pm 7.72$ & $41.90 \pm 2.65$ \\
\hline $10 \mathrm{mg} / \mathrm{kg} \mathrm{E} 4+16 \mathrm{mg} / \mathrm{kg} \mathrm{P4}$ & $174.60 \pm 12.38$ & $73.50 \pm 6.97$ & $58.40 \pm 4.74$ & $46.30 \pm 4.57$ & $38.40 \pm 5.45$ \\
\hline $10 \mathrm{mg} / \mathrm{kg} \mathrm{E4}+16 \mathrm{mg} / \mathrm{kg} \mathrm{P4+136ng/kg} \mathrm{E2}$ & $115.70 \pm 6.51$ & $52.70 \pm 2.49$ & $45.00 \pm 3.63$ & $46.30 \pm 5.02$ & $36.90 \pm 3.485$ \\
\hline $10 \mathrm{mg} / \mathrm{kg} \mathrm{E4}+136 \mathrm{ng} / \mathrm{kg} \mathrm{E2}$ & $131.70 \pm 8.94$ & $56.30 \pm 3.02$ & $57.70 \pm 2.46$ & $43.30 \pm 1.89$ & $39.50 \pm 4.37$ \\
\hline \multicolumn{6}{|l|}{ Treatment } \\
\hline Sham & $202.70 \pm 18.28$ & $89.80 \pm 8.57 \# \#$ & $55.40 \pm 3.34$ & $44.70 \pm 32.38 \dagger$ & $47.20 \pm 3.90$ \\
\hline Vehicle & $74.00 \pm 10.61 \S$ & $39.10 \pm 6.79$ & $41.80 \pm 6.86$ & $24.30 \pm 4.15$ & $20.30 \pm 2.33 \dagger \dagger$ \\
\hline $5 \mathrm{mg} / \mathrm{kg} \mathrm{E4}$ & $142.90 \pm 5.63$ & $60.40 \pm 3.55$ & $56.30 \pm 3.45$ & $32.90 \pm 31.62$ & $32.70 \pm 2.64$ \\
\hline $5 \mathrm{mg} / \mathrm{kg} \mathrm{E4}+1.6 \mathrm{mg} / \mathrm{kg} \mathrm{P4}$ & $138.80 \pm 14.01$ & $45.20 \pm 4.20$ & $53.20 \pm 5.67$ & $34.60 \pm 33.21$ & $42.30 \pm 3.72$ \\
\hline $5 \mathrm{mg} / \mathrm{kg} \mathrm{E4+1.6mg/kg} \mathrm{P4+136ng/kg} \mathrm{E2}$ & $160.00 \pm 7.29$ & $61.10 \pm 3.94$ & $56.50 \pm 2.79$ & $39.50 \pm 31.46$ & $41.40 \pm 4.79$ \\
\hline $5 \mathrm{mg} / \mathrm{kg} \mathrm{E4}+16 \mathrm{mg} / \mathrm{kg} \mathrm{P4}$ & $175.50 \pm 7.84$ & $61.30 \pm 3.08$ & $55.10 \pm 3.85$ & $42.5 \pm 31.87$ & $50.90 \pm 4.87$ \\
\hline $5 \mathrm{mg} / \mathrm{kg} \mathrm{E4}+16 \mathrm{mg} / \mathrm{kg} \mathrm{P4+136ng/kg} \mathrm{E2}$ & $164.00 \pm 12.45$ & $58.4 \pm 4.92$ & $57.50 \pm 4.17$ & $35.6 \pm 33.45$ & $37.00 \pm 4.17$ \\
\hline $5 \mathrm{mg} / \mathrm{kg} \mathrm{E4+136ng/kg} \mathrm{E2}$ & $128.50 \pm 12.15$ & $54.10 \pm 4.37$ & $54.20 \pm 4.95$ & $38.00 \pm 34.13$ & $46.00 \pm 4.51$ \\
\hline $10 \mathrm{mg} / \mathrm{kg} \mathrm{E4}$ & $150.20 \pm 9.43$ & $57.30 \pm 5.19$ & $51.20 \pm 2.82$ & $33.50 \pm 0.98$ & $46.60 \pm 1.83$ \\
\hline $10 \mathrm{mg} / \mathrm{kg} \mathrm{E} 4+1.6 \mathrm{mg} / \mathrm{kg} \mathrm{P4}$ & $132.20 \pm 13.68$ & $41.90 \pm 2.88$ & $47.10 \pm 6.64$ & $37.60 \pm 33.36$ & $31.30 \pm 3.83$ \\
\hline $10 \mathrm{mg} / \mathrm{kg} \mathrm{E4}+1.6 \mathrm{mg} / \mathrm{kg} \mathrm{P4}+136 \mathrm{ng} / \mathrm{kg} \mathrm{E2}$ & $156.00 \pm 6.11$ & $56.70 \pm 2.45$ & $61.50 \pm 2.88$ & $39.80 \pm 31.30$ & $38.80 \pm 4.81$ \\
\hline $10 \mathrm{mg} / \mathrm{kg} \mathrm{E4}+16 \mathrm{mg} / \mathrm{kg} \mathrm{P4}$ & $168.40 \pm 4.38$ & $65.40 \pm 3.09$ & $57.50 \pm 1.73$ & $40.40 \pm 31.83$ & $48.10 \pm 4.02$ \\
\hline $10 \mathrm{mg} / \mathrm{kg} \mathrm{E} 4+16 \mathrm{mg} / \mathrm{kg} \mathrm{P4}+136 \mathrm{ng} / \mathrm{kg} \mathrm{E2}$ & $150.00 \pm 9.92$ & $54.40 \pm 4.01$ & $50.90 \pm 4.59$ & $32.60 \pm 32.82$ & $39.10 \pm 3.30$ \\
\hline $10 \mathrm{mg} / \mathrm{kg} \mathrm{E4+136ng/kg} \mathrm{E2}$ & $103.40 \pm 13.47 \S \S$ & $41.50 \pm 5.55$ & $48.40 \pm 6.86$ & $28.90 \pm 35.34$ & $39.10 \pm 3.45$ \\
\hline
\end{tabular}

Significant differences were observed:

in the DG region

pretreated groups:

*sham vs. $5 \mathrm{mg} / \mathrm{kg} / \mathrm{d}$ E4+136ng $/ \mathrm{kg} / \mathrm{d}$ E2, $5 \mathrm{mg} / \mathrm{kg} / \mathrm{d}$ E4+16mg/kg/d P4+136ng $/ \mathrm{kg} / \mathrm{d} \mathrm{E} 2,10 \mathrm{mg} / \mathrm{kg} / \mathrm{d}+16 \mathrm{mg} / \mathrm{kg} / \mathrm{d}$ P4+136ng/ $\mathrm{kg} / \mathrm{d}$ E2;

** vehicle $v$ s. sham, $5 \mathrm{mg} / \mathrm{kg} / \mathrm{day}$ E4, $5 \mathrm{mg} / \mathrm{kg} /$ day E4+1.6mg $/ \mathrm{kg} / \mathrm{d}$ P4, $5 \mathrm{mg} / \mathrm{kg} / \mathrm{day}$ E4+1.6mg $/ \mathrm{kg} / \mathrm{d}$ P4+136ng $/ \mathrm{kg} / \mathrm{d} \mathrm{E} 2,10 \mathrm{mg} /$ $\mathrm{kg} / \mathrm{d}$ E4, $10 \mathrm{mg} / \mathrm{kg} / \mathrm{day}$ E4+1.6mg/kg/d P4, 10mg/kg/day E4+16mg/kg/d P4;

*** $10 \mathrm{mg} / \mathrm{kg} / \mathrm{d}$ E4 vs. vehicle, sham, $10 \mathrm{mg} / \mathrm{kg} / \mathrm{d}$ E4+1.6mg $/ \mathrm{kg} / \mathrm{d}$ P4+136ng $/ \mathrm{kg} / \mathrm{d}$ E2, 10mg/kg/d E4+16mg $/ \mathrm{kg} / \mathrm{d}$ P4+136ng/ $\mathrm{kg} / \mathrm{d} \mathrm{E} 2,10 \mathrm{mg} / \mathrm{kg} / \mathrm{d} \mathrm{E} 4+136 \mathrm{ng} / \mathrm{kg} / \mathrm{d} \mathrm{E} 2$;

treated groups:

§vehicle vs. sham, $5 \mathrm{mg} / \mathrm{kg} / \mathrm{d}$ E4+1.6mg $/ \mathrm{kg} / \mathrm{d}$ P4+136ng $/ \mathrm{kg} / \mathrm{d}$ E2, $5 \mathrm{mg} / \mathrm{kg} / \mathrm{d}$ E4+16mg $/ \mathrm{kg} / \mathrm{d}$ P4, $5 \mathrm{mg} / \mathrm{kg} / \mathrm{d}$ E4+16mg $/ \mathrm{kg} / \mathrm{d}$ P4+136ng $/ \mathrm{kg} / \mathrm{d}$ E2, $10 \mathrm{mg} / \mathrm{kg} / \mathrm{d} \mathrm{E} 4+1.6 \mathrm{mg} / \mathrm{kg} / \mathrm{d} \mathrm{P} 4+136 \mathrm{ng} / \mathrm{kg} / \mathrm{d} \mathrm{E} 2,10 \mathrm{mg} / \mathrm{kg} / \mathrm{d} \mathrm{E} 4,10 \mathrm{mg} / \mathrm{kg} / \mathrm{d} \mathrm{E} 4+16 \mathrm{mg} / \mathrm{kg} / \mathrm{d} \mathrm{P} 4,10 \mathrm{mg} / \mathrm{kg} / \mathrm{d}$ $\mathrm{E} 4+16 \mathrm{mg} / \mathrm{kg} / \mathrm{d}$ P4+136ng/kg/d E2; $\S 10 \mathrm{mg} / \mathrm{kg} / \mathrm{d}$ E4+136ng $/ \mathrm{kg} / \mathrm{d}$ E2 vs. sham group in treated groups;

in the SGZ

pretreated groups:

$\S \S \S$ sham $v s .5 \mathrm{mg} / \mathrm{kg} / \mathrm{d} \mathrm{E} 4+136 \mathrm{ng} / \mathrm{kg} / \mathrm{d} \mathrm{E} 2$

\#vehicle vs. sham, $5 \mathrm{mg} / \mathrm{kg} / \mathrm{d}$ E4, $5 \mathrm{mg} / \mathrm{kg} / \mathrm{d}+16 \mathrm{mg} / \mathrm{kg} / \mathrm{d} \mathrm{P} 4+136 \mathrm{ng} / \mathrm{kg} / \mathrm{d}$ E2, 10mg/kg/d E4, 10mg/kg/d E4+16mg/kg/d P4; 
treated groups:

\#\#sham vs. vehicle, $5 \mathrm{mg} / \mathrm{kg} / \mathrm{d}+136 \mathrm{ng} / \mathrm{kg} / \mathrm{d}$ E2, $5 \mathrm{mg} / \mathrm{kg} / \mathrm{d}+1.6 \mathrm{mg}+\mathrm{kg}+\mathrm{d}$ P $4,10 \mathrm{mg} / \mathrm{kg} / \mathrm{d}$ E4+1.6mg/kg/d P4, 10mg/kg/d E4+1.6mg/kg/d P4+136ng/kg/d E2, $10 \mathrm{mg} / \mathrm{kg} / \mathrm{d} \mathrm{E} 4+16 \mathrm{mg} / \mathrm{kg} / \mathrm{d}$ P4+136ng/kg/d E2, 10mg/kg/d E4+136ng/kg/d E2;

in the $\mathrm{CA} 2 / \mathrm{CA} 3$ region

treated groups:

$\dagger$ sham vs. vehicle in treated groups;

in the Cortex-

treated groups:

†† vehicle $v s$. sham, $5 \mathrm{mg} / \mathrm{kg} / \mathrm{d}+16 \mathrm{mg} / \mathrm{kg} / \mathrm{d}$ P4, $10 \mathrm{mg} / \mathrm{kg} / \mathrm{d}, 10 \mathrm{mg} / \mathrm{kg} / \mathrm{d}+16 \mathrm{mg} / \mathrm{kg} / \mathrm{d} \mathrm{P} 4$;

\section{Hematoxylin-eosin staining and intact cell counting}

Coronal sections from rat pups brains pretreated/ treated by the vehicle showed injury of the hippocampus at the left carotid artery occlusion side which was extended to the cortex (Figure 3A(b), 3B(b)). As demonstrated in Table 2 in the hippocampal dentate gyrus (DG) region in pretreated groups the sham group showed significantly
(A)

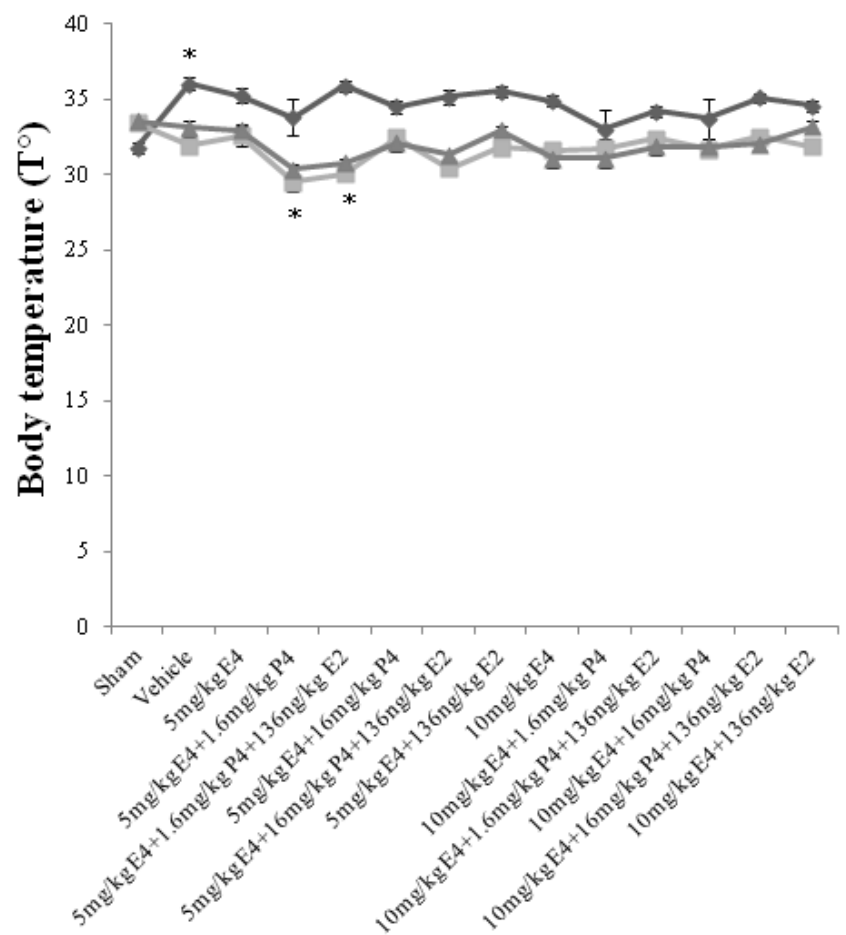

(B)

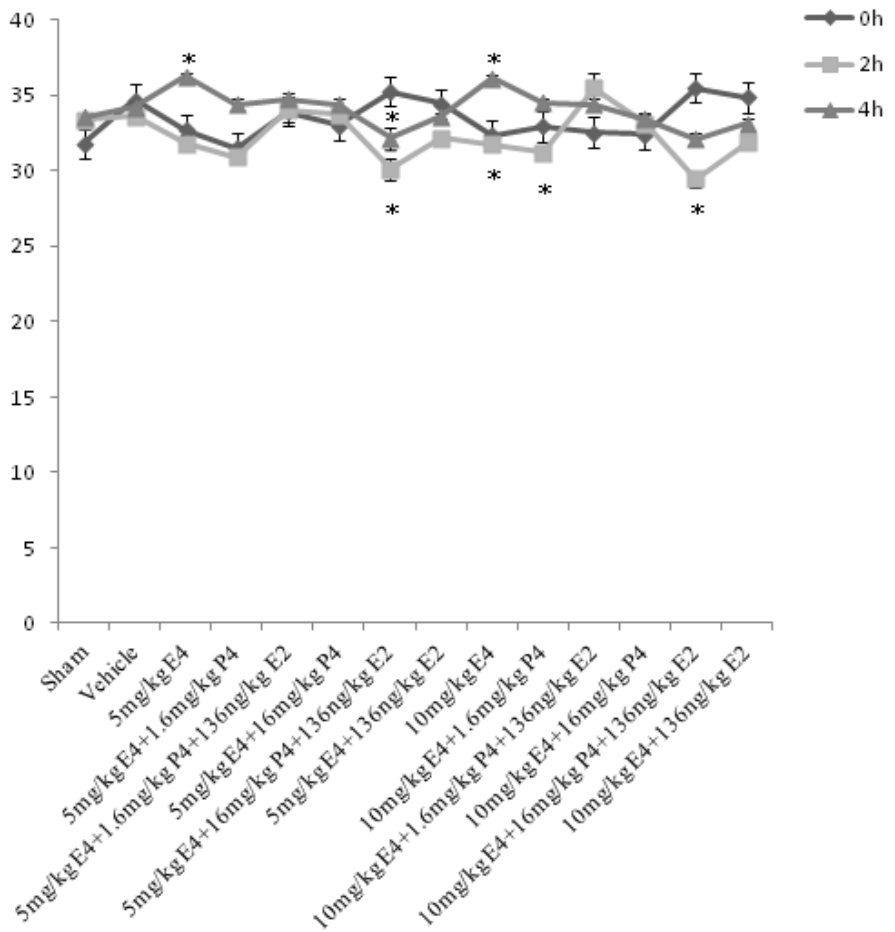

Figure 2: Post-operative rectal temperature and body weight of rat pups. A. In neuroprotective model, immediately after hypoxic-ischemic (HI) insult (at $0 \mathrm{~h}$ ), the rectal temperature was significantly increased only in the vehicle group than in the sham group, whereas $2 \mathrm{~h}$ later the rectal temperature was significantly decreased in pretreated by $5 \mathrm{mg} / \mathrm{kg} /$ day E4 and $1.6 \mathrm{mg} / \mathrm{kg} / \mathrm{day} \mathrm{P} 4 \mathrm{with} / \mathrm{without}$ $136 \mathrm{ng} / \mathrm{kg} /$ day E2 groups compared to the sham group. 4h later no significant difference was observed among the study groups. B. In therapeutic model, between the study groups immediately after $\mathrm{HI}$ insult no significant differences were detected, whereas $2 \mathrm{~h}$ later groups treated by combination of $5 \mathrm{mg} / \mathrm{kg}$ /day or $10 \mathrm{mg} / \mathrm{kg} /$ day E4 with $16 \mathrm{mg} / \mathrm{kg} /$ day P4 plus $136 \mathrm{ng} / \mathrm{kg} /$ day E2 had significantly decreased rectal temperature than the vehicle group or the groups treated by the same doses of E4 with $1.6 \mathrm{mg} / \mathrm{kg} / \mathrm{day}$ P4 and E2. Moreover, combination of $10 \mathrm{mg} / \mathrm{kg} /$ day E4 with $16 \mathrm{mg} / \mathrm{kg} /$ day P4 and $136 \mathrm{ng} / \mathrm{kg} /$ day E2 significantly downregulated the rectal temperature compared to the sham group, or the group treated by $10 \mathrm{mg} / \mathrm{kg} / \mathrm{day}$ E4 and $16 \mathrm{mg} / \mathrm{kg} /$ day P4 (Figure 2B). Also, the groups treated by $10 \mathrm{mg} / \mathrm{kg} / \mathrm{day}$ E4 alone or combined with $1.6 \mathrm{mg} / \mathrm{kg} / \mathrm{day} \mathrm{P} 4$ had significantly decreased rectal temperature compared to the group treated by $10 \mathrm{mg} / \mathrm{kg} / \mathrm{day} \mathrm{E} 4 \mathrm{with}$ $1.6 \mathrm{mg} / \mathrm{kg} /$ day P4 and 136ng/kg/day E2. At $4 \mathrm{~h}$ after HI event, animals treated by $5 \mathrm{mg} / \mathrm{kg} /$ day or $10 \mathrm{mg} / \mathrm{kg} / \mathrm{day} \mathrm{E} 4 \mathrm{and} 136 \mathrm{ng} / \mathrm{kg} / \mathrm{day}$ E2 with/ without $16 \mathrm{mg} / \mathrm{kg} /$ day P4 had significantly decreased rectal temperature along with the sham group compared to animals treated by single doses of E4 (Figure 2B). The same pattern was observed between groups treated by $10 \mathrm{mg} / \mathrm{kg} /$ day E4 with $1.6 \mathrm{mg} / \mathrm{kg} / \mathrm{day}$ P4 and $136 \mathrm{ng} / \mathrm{kg} /$ day E2, and the group treated by E4 alone. Treatment by $5 \mathrm{mg} / \mathrm{kg} /$ day E4 with $16 \mathrm{mg} / \mathrm{kg} /$ day P4 and 136ng/kg/day E2 significantly decreased the rectal temperature than the treatment by the same combination of compounds with $1.6 \mathrm{mg} / \mathrm{kg} / \mathrm{day}$ P4 (Figure 2B). All measurements are expressed as mean \pm SEM. ${ }^{*} p \leq 0.05$. 
Table 3: Percentage of the DCX and VEGF-positively stained cells in combinedly pretreated/treated groups.

\begin{tabular}{|c|c|c|c|c|c|c|c|c|}
\hline Groups & DG & CA1 & CA2/CA3 & Cortex & DG & CA1 & CA2/CA3 & Cortex \\
\hline & DCX & DCX & DCX & DCX & VEGF & VEGF & VEGF & VEGF \\
\hline \multicolumn{9}{|l|}{ Pretreatment } \\
\hline Sham & $59.73 \pm 3.44$ & $52.34 \pm 30.99$ & $51.25 \pm 2.42$ & $63.34 \pm 2.17$ & $52.38 \pm 1.58$ & $51.87 \pm 3.68$ & $55.79 \pm 2.92$ & $58.29 \pm 2.98$ \\
\hline Vehicle & $30.90 \pm 3.97$ & $\begin{array}{l}16.78 \pm 32.36 \\
\# \# \#\end{array}$ & $15.97 \pm 2.35$ & $\begin{array}{l}29.48 \pm 1.98 \\
* \#\end{array}$ & $31.25 \pm 3.70$ & $\begin{array}{l}20.76 \pm 2.71 \\
\S\end{array}$ & $20.05 \pm 3.01$ & $\begin{array}{l}28.47 \pm 2.13 \\
* * \#\end{array}$ \\
\hline $5 \mathrm{mg} / \mathrm{kg} \mathrm{E4}$ & $60.29 \pm 5.66$ & $45.97 \pm 34.40$ & $\begin{array}{l}32.38 \pm 5.03 \\
* \S\end{array}$ & $51.47 \pm 3.98$ & $42.81 \pm 2.68$ & $49.99 \pm 3.94$ & $43.80 \pm 3.68$ & $46.00 \pm 2.55$ \\
\hline $\begin{array}{l}5 \mathrm{mg} / \mathrm{kg} \mathrm{E} 4+1.6 \mathrm{mg} / \mathrm{kg} \\
P 4\end{array}$ & $45.16 \pm 3.26$ & $42.67 \pm 35.07$ & $34.03 \pm 5.62$ & $51.89 \pm 5.26$ & $38.60 \pm 3.32$ & $44.96 \pm 5.04$ & $42.96 \pm 3.70$ & $40.31 \pm 4.95$ \\
\hline $\begin{array}{l}5 m g / k g \quad E 4+1.6 m g / k g \\
P 4+136 n g / k g \text { E2 }\end{array}$ & $8.55 \pm 5.37$ & $37.08 \pm 32.67$ & $22.68 \pm 2.81$ & $53.98 \pm 3.81$ & $47.71 \pm 4.36$ & $36.17 \pm 3.17$ & $31.14 \pm 2.87$ & $39.23 \pm 2.69$ \\
\hline $\begin{array}{l}5 \mathrm{mg} / \mathrm{kg} \quad \mathrm{E} 4+16 \mathrm{mg} / \mathrm{kg} \\
\mathrm{P} 4\end{array}$ & $56.23 \pm 4.02$ & $51.34 \pm 34.00$ & $49.02 \pm 9.09$ & $71.46 \pm 4.89$ & $44.53 \pm 2.50$ & $59.56 \pm 3.26$ & $51.57 \pm 6.77$ & $60.22 \pm 4.09$ \\
\hline 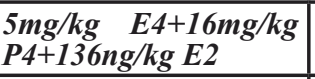 & $53.40 \pm 3.56$ & $32.41 \pm 39.50$ & $27.43 \pm 9.36$ & $53.06 \pm 3.10$ & $46.67 \pm 2.59$ & $42.49 \pm 8.47$ & $41.07 \pm 7.66$ & $49.67 \pm 4.23$ \\
\hline $\begin{array}{l}\mathrm{mg} / \mathrm{kg} \mathrm{E4}+136 \mathrm{ng} / \mathrm{kg} \\
E 2\end{array}$ & $33.49 \pm 4.53$ & $42.61 \pm 35.66$ & $36.19 \pm 3.25$ & $52.05 \pm 3.92$ & $46.84 \pm 2.56$ & $50.07 \pm 4.74$ & $46.74 \pm 3.87$ & $43.20 \pm 4.02$ \\
\hline $10 \mathrm{mg} / \mathrm{kg} \mathrm{E4}$ & $50.43 \pm 4.56$ & $39.96 \pm 33.60$ & $26.58 \pm 2.8$ & $56.12 \pm 6.10$ & $51.44 \pm 3.29$ & $49.21 \pm 3.49$ & $38.31 \pm 4.33$ & $52.90 \pm 5.81$ \\
\hline $\begin{array}{l}10 \mathrm{mg} / \mathrm{kg} \quad \mathrm{E} 4+1.6 \mathrm{mg} / \\
\mathrm{kg} \mathrm{P4}\end{array}$ & $45.02 \pm 5.92$ & $31.59 \pm 36.83$ & $18.11 \pm 3.46$ & $44.88 \pm 7.95$ & $42.77 \pm 3.97$ & $39.57 \pm 6.49$ & $39.64 \pm 6.07$ & $46.93 \pm 6.38$ \\
\hline $\begin{array}{l}10 \mathrm{mg} / \mathrm{kgE} 4+1.6 \mathrm{mg} / \mathrm{kg} \\
P 4+136 \mathrm{ng} / \mathrm{kg} \mathrm{E2}\end{array}$ & $53.25 \pm 3.17$ & $38.75 \pm 35.03$ & $36.12 \pm 4.79$ & $56.97 \pm 7.53$ & $55.34 \pm 2.35$ & $34.83 \pm 3.38$ & $42.80 \pm 5.43$ & $52.93 \pm 5.54$ \\
\hline $\begin{array}{lll}10 \mathrm{mg} / \mathrm{kg} & \mathrm{E} 4 & +16 \mathrm{mg} / \\
\mathrm{kg} \mathrm{P4} & & \end{array}$ & $44.50 \pm 2.96$ & $32.18 \pm 35.74$ & $27.73 \pm 6.12$ & $49.22 \pm 4.72$ & $47.05 \pm 3.30$ & $32.57 \pm 4.74$ & $34.51 \pm 7.05$ & $38.10 \pm 4.57$ \\
\hline $\begin{array}{l}10 \mathrm{mg} / \mathrm{kg} \mathrm{E4}+16 \mathrm{mg} / \mathrm{kg} \\
P 4+136 \mathrm{hg} / \mathrm{kg} \mathrm{E2}\end{array}$ & $45.86 \pm 3.28$ & $30.73 \pm 34.99$ & $22.41 \pm 4.47$ & $53.04 \pm 5.04$ & $43.87 \pm 3.22$ & $37.30 \pm 3.13$ & $36.25 \pm 6.02$ & $38.03 \pm 3.25$ \\
\hline $\begin{array}{l}10 \mathrm{mg} / \mathrm{kg} \mathrm{E} \mathrm{E} 4+136 \mathrm{ng} / \\
\mathrm{kgE2}\end{array}$ & $39.25 \pm 1.63$ & $41.02 \pm 34.96$ & $46.71 \pm 3.76$ & $52.02 \pm 3.34$ & $48.40 \pm 2.66$ & $49.99 \pm 3.20$ & $51.74 \pm 5.20$ & $45.40 \pm 3.63$ \\
\hline \multicolumn{9}{|l|}{ Treatment } \\
\hline Sham & $\begin{array}{l}\text { 59.73 } \pm 3.44 \\
\#\end{array}$ & $52.43 \pm 0.99$ & $51.25 \pm 2.42$ & $63.34 \pm 2.17$ & $52.38 \pm 1.58$ & $51.87 \pm 3.68$ & $55.79 \pm 2.92$ & $58.29 \pm 2.98$ \\
\hline Vehicle & $30.25 \pm 4.90$ & $\begin{array}{l}23.17 \pm 4.43 \\
\S \S \\
\end{array}$ & $16.96 \pm 3.67$ & $\begin{array}{l}31.01 \pm 3.90 \\
* \# \#\end{array}$ & $\begin{array}{l}29.87 \pm 2.88 \\
\# \#\end{array}$ & $\begin{array}{l}\text { 21.95 } \pm 2.48 \\
\S \S \S\end{array}$ & $\begin{array}{l}22.93 \pm 2.37 \\
* \S \S \\
\end{array}$ & $\begin{array}{l}27.85 \pm 2.80 \\
* \dagger\end{array}$ \\
\hline $5 \mathrm{mg} / \mathrm{kg} \mathrm{E4}$ & $55.72 \pm 2.91$ & $36.63 \pm 4.00$ & $15.09 \pm 2.12$ & $61.28 \pm 6.10$ & $54.05 \pm 3.51$ & $36.54 \pm 3.15$ & $34.12 \pm 3.54$ & $40.72 \pm 4.85$ \\
\hline $\begin{array}{l}5 \mathrm{mg} / \mathrm{kgE} 4 \\
+1.6 \mathrm{mg} / \mathrm{kg} \mathrm{P4} \\
\end{array}$ & $37.27 \pm 3.44$ & $34.00 \pm 5.20$ & $24.45 \pm 5.83$ & $52.05 \pm 6.93$ & $43.07 \pm 3.66$ & $36.96 \pm 7.55$ & $40.78 \pm 9.06$ & $44.91 \pm 5.89$ \\
\hline $\begin{array}{l}5 \mathrm{mg} / \mathrm{kg} \quad \mathrm{E4}+1.6 \mathrm{mg} / \mathrm{kg} \\
P 4+136 \mathrm{ng} / \mathrm{kg} \mathrm{E2}\end{array}$ & $34.85 \pm 2.10$ & $36.95 \pm 3.00$ & $30.95 \pm 3.64$ & $53.75 \pm 4.25$ & $41.34 \pm 2.37$ & $35.08 \pm 3.94$ & $33.83 \pm 5.17$ & $45.44 \pm 3.91$ \\
\hline $\begin{array}{l}\mathrm{mg} / \mathrm{kg} \mathrm{E4}+16 \mathrm{mg} / \mathrm{kg} \\
\mathrm{P4}\end{array}$ & $53.06 \pm 2.55$ & $43.67 \pm 3.16$ & $46.37 \pm 3.61$ & $47.08 \pm 5.96$ & $54.97 \pm 3.07$ & $49.78 \pm 2.58$ & $52.41 \pm 4.25$ & $45.84 \pm 5.02$ \\
\hline $\begin{array}{l}5 \mathrm{mg} / \mathrm{kg} \quad \mathrm{E4}+16 \mathrm{mg} / \mathrm{kg} \\
P 4+136 \mathrm{ng} / \mathrm{kg} \mathrm{E2}\end{array}$ & $41.97 \pm 2.02$ & $43.27 \pm 2.84$ & $38.16 \pm 3.91$ & $39.14 \pm 3.92$ & $42.71 \pm 3.02$ & $44.08 \pm 4.12$ & $35.17 \pm 3.88$ & $34.58 \pm 3.06$ \\
\hline $\begin{array}{l}\mathrm{mg} / \mathrm{kg} \mathrm{E4}+136 \mathrm{ng} / \mathrm{kg} \\
E 2\end{array}$ & $41.69 \pm 2.75$ & $54.47 \pm 4.17$ & $43.03 \pm 5.13$ & $53.37 \pm 3.72$ & $40.10 \pm 4.40$ & $50.32 \pm 3.00$ & $43.75 \pm 3.83$ & $36.50 \pm 3.17$ \\
\hline $10 \mathrm{mg} / \mathrm{kg} \mathrm{E4}$ & $43.67 \pm 2.26$ & $41.08 \pm 2.47$ & $36.18 \pm 3.70$ & $53.88 \pm 3.90$ & $44.65 \pm 3.38$ & $46.16 \pm 2.96$ & $49.14 \pm 3.84$ & $46.66 \pm 3.90$ \\
\hline $\begin{array}{ll}10 \mathrm{mg} / \mathrm{kg} & \mathrm{E} 4+1.6 \mathrm{mg} / \\
\mathrm{kg} \mathrm{P} 4 & \end{array}$ & $49.64 \pm 4.35$ & $45.286 \pm 4.01$ & $52.53 \pm 5.02$ & $44.61 \pm 5.31$ & $43.31 \pm 3.97$ & $51.91 \pm 1.57$ & $49.58 \pm 4.25$ & $41.96 \pm 6.01$ \\
\hline $\begin{array}{l}10 \mathrm{mg} / \mathrm{kgE} 4+1.6 \mathrm{mg} / \mathrm{kg} \\
P 4+136 \mathrm{ng} / \mathrm{kg} \mathrm{E2}\end{array}$ & $37.73 \pm 3.38$ & $44.74 \pm 7.93$ & $31.47 \pm 6.98$ & $47.19 \pm 6.10$ & $46.97 \pm 3.91$ & $39.40 \pm 3.79$ & $40.78 \pm 4.16$ & $34.81 \pm 3.12$ \\
\hline $\begin{array}{l}10 \mathrm{mg} / \mathrm{kg} \quad \mathrm{E} 4+16 \mathrm{mg} / \\
\mathrm{kgP4}\end{array}$ & $41.10 \pm 4.00$ & $48.83 \pm 2.69$ & $46.83 \pm 3.53$ & $62.66 \pm 3.74$ & $46.85 \pm 3.19$ & $50.72 \pm 3.83$ & $52.68 \pm 3.94$ & $48.70 \pm 3.76$ \\
\hline $\begin{array}{l}10 \mathrm{mg} / \mathrm{kg} \mathrm{E} \text { E+16mg/kg } \\
P 4+136 \mathrm{ng} / \mathrm{kg} \mathrm{E2}\end{array}$ & $33.53 \pm 1.70$ & $30.11 \pm 2.24$ & $27.84 \pm 4.31$ & $42.81 \pm 2.93$ & $45.08 \pm 1.75$ & $40.39 \pm 3.51$ & $39.24 \pm 4.96$ & $37.98 \pm 3.76$ \\
\hline $\begin{array}{l}\text { 10mg/kg E4 +136ng/ } \\
\mathrm{kg} \mathrm{E2}\end{array}$ & $39.89 \pm 3.20$ & $38.39 \pm 6.74$ & $42.00 \pm 5.22$ & $46.20 \pm 3.74$ & $47.03 \pm 3.82$ & $44.97 \pm 8.41$ & $40.61 \pm 6.51$ & $39.07 \pm 3.32$ \\
\hline
\end{tabular}

Significant differences were observed:

in the $D G$ region 
pretreated groups:

DCX-stained cells -*vehicle $v s$. sham, $5 \mathrm{mg} / \mathrm{kg} / \mathrm{d}$ E4, VEGF-stained cells-**vehicle vs. sham, 5mg/kg/d E4+16mg/kg/d P4; treated groups:

DCX stained cells-*** vehicle $v s$. sham, $5 \mathrm{mg} / \mathrm{kg} / \mathrm{d} \mathrm{E} 4,5 \mathrm{mg} / \mathrm{kg} / \mathrm{d}$ E4+16mg/kg/d P4, \# sham vs. $5 \mathrm{mg} / \mathrm{kg} / \mathrm{d} \mathrm{E} 4+1.6 \mathrm{mg} / \mathrm{kg} / \mathrm{d}$ $\mathrm{P} 4,5 \mathrm{mg} / \mathrm{kg} / \mathrm{d} \mathrm{E} 4+1.6 \mathrm{mg} / \mathrm{kg} / \mathrm{d}$ P4+136ng/ $/ \mathrm{kg} / \mathrm{d} \mathrm{E} 2,10 \mathrm{mg} / \mathrm{kg} / \mathrm{d} \mathrm{E} 4+1.6 \mathrm{mg} / \mathrm{kg} / \mathrm{d} \mathrm{P} 4+136 \mathrm{ng} / \mathrm{kg} / \mathrm{d} \mathrm{E} 2,10 \mathrm{mg} / \mathrm{kg} / \mathrm{d}$ E4+16mg/kg/d $\mathrm{P} 4+136 \mathrm{ng} / \mathrm{kg} / \mathrm{d}$ E2;

VEGF stained cells-\#\# vehicle $v s$. sham, $5 \mathrm{mg} / \mathrm{kg} / \mathrm{d}$ E4, $5 \mathrm{mg} / \mathrm{kg} / \mathrm{d} \mathrm{E} 4+16 \mathrm{mg} / \mathrm{kg} / \mathrm{d}$ P4;

in the $\mathrm{CA1}$ region

pretreated groups:

DCX-stained cells-\#\#\# vehicle vs. sham, VEGF-stained cells- $\S$ vehicle $v s$. sham, $5 \mathrm{mg} / \mathrm{kg} / \mathrm{d}+16 \mathrm{mg} / \mathrm{kg} / \mathrm{d}$ P4;

treated groups:

DCX-stained cells- §§vehicle vs. sham, $5 \mathrm{mg} / \mathrm{kg} / \mathrm{d}$ E4+136ng/kg/d E2, VEGF-stained cells-§§§vehicle vs. sham, 10mg/kg/d

$\mathrm{E} 4+1.6 \mathrm{mg} / \mathrm{kg} / \mathrm{d} \mathrm{P} 4$;

in the $\mathrm{CA} 2 / \mathrm{CA} 3$ region

pretreated groups: DCX-stained cells- $\dagger$ vehicle vs. sham, VEGF stained cells- $\dagger \dagger$ vehicle vs. sham;

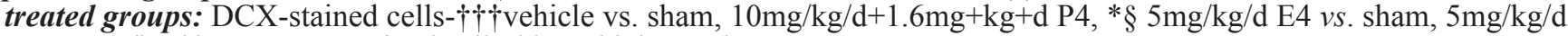
E4+16mg/kg /d P4, VEGF stained cells- $* * \S$ vehicle vs. sham,

in the Cortex

pretreated groups:

DCX-stained cells-*\#vehicle vs. sham, $5 \mathrm{mg} / \mathrm{kg} / \mathrm{d}$ E4+16mg/kg/d P4, VEGF-stained cells-**\# vehicle vs. sham, 5mg/kg/d $\mathrm{E} 4+16 \mathrm{mg} / \mathrm{kg} / \mathrm{d} \mathrm{P} 4$;

treated groups: DCX-stained cells- *\#\# vehicle vs. sham, VEGF-stained cells- *†vehicle vs. sham.

higher intact cell counting compared to the animals pretreated either with the vehicle or by $5 \mathrm{mg} / \mathrm{kg} / \mathrm{d} \mathrm{E} 4$ and E2 with/without $16 \mathrm{mg} / \mathrm{kg} / \mathrm{d}$ P4 (Figure $3 \mathrm{~A}(\mathrm{c}),(\mathrm{d})$, respectively) or by $10 \mathrm{mg} / \mathrm{kg} / \mathrm{d} \mathrm{E} 4$ with E2 and $16 \mathrm{mg} / \mathrm{kg} / \mathrm{d}$ P4 (Supp. Figure 1 (A)). Significantly higher number of intact cells was observed in animals pretreated by $5 \mathrm{mg} /$ $\mathrm{kg} / \mathrm{d}$ E4 (Figure 3A(c)) and 10mg/kg/d E4 (Figure 3A (f)) alone or in combination with $1.6 \mathrm{mg} / \mathrm{kg} / \mathrm{d} \mathrm{P} 4$ and/or E2, also in animals pretreated with $10 \mathrm{mg} / \mathrm{kg} / \mathrm{d}$ and $16 \mathrm{mg} /$ $\mathrm{kg} / \mathrm{d}$ P4 compared to the vehicle group (Table 2). Among pretreated groups, significant differences were defined between animals pretreated by $10 \mathrm{mg} / \mathrm{kg} / \mathrm{d} \mathrm{E} 4$ alone or in combination with E2 and/or any concentration of P4, and the sham group (Table 2).

In treated groups (Figure 3B), in the hippocampus DG region the number of intact cells was significantly decreased in animals from the vehicle group compared to the sham group, also in animals treated by combination of different doses of E4 either with any dose of P4 and/ or E2. Intact cell number was significantly downregulated in animals combinedly treated by $10 \mathrm{mg} / \mathrm{kg} / \mathrm{d} \mathrm{E} 4$ and E2 (Figure 3B (h)) compared to the sham group (Table2).

In pretreated groups, in the subgranular region (SGZ) of hippocampus, the sham group had significantly higher intact cell counting than animals pretreated by $5 \mathrm{mg} /$ $\mathrm{kg} / \mathrm{d}$ E4 with E2 (Figure 3A (h)), whereas the number of intact cells was significantly downregulated in animals from the vehicle group compared to sham group and the groups pretreated by different doses of E4 alone or combined with $16 \mathrm{mg} / \mathrm{kg} / \mathrm{d}$ P4. The same pattern of significant difference was observed in animals pretreated by $5 \mathrm{mg} / \mathrm{kg} / \mathrm{d}$ E4 in combination with $16 \mathrm{mg} / \mathrm{kg} / \mathrm{d} \mathrm{P} 4$ plus E2 and the vehicle group (Table 2).

In treated groups, in the SGZ region significant differences were observed between the vehicle group and the animals treated by different doses of E4 with $1.6 \mathrm{mg} / \mathrm{kg} / \mathrm{d}$ P4 or E2, also the animals treated by $10 \mathrm{mg} /$ $\mathrm{kg} / \mathrm{d}$ E4 with E2 and different doses of P4 (Supp. Figure 1 (B)), (Table 2). In the CA2/CA3 region among treated groups the intact cell counting was significantly different only among animals from sham and the vehicle groups, whereas in the cortex significantly higher number of intact cells was detected in sham group along with groups treated either by different doses of E4 in combination with $16 \mathrm{mg}$ / $\mathrm{kg} / \mathrm{d} \mathrm{P} 4$ or $10 \mathrm{mg} / \mathrm{kg} / \mathrm{d} \mathrm{E} 4$ alone (Figure $3 \mathrm{~B}$ ) and the vehicle group (Table2).

\section{MAP-2 staining}

For evaluation of gray matter loss MAP2 staining was used. In sections from the vehicle pretreated/treated animals was observed an existence of MAP2 negatively stained areas in the hippocampus and the cortex at the left, damaged side (Supp. Figure 2 (A), (B)). Calculations of MAP-2 positive area ratios showed that after pretreatment with different combinations of steroids the ratio of MAP2positively stained area was significantly upregulated in animals pretreated by $10 \mathrm{mg} / \mathrm{kg} / \mathrm{d} \mathrm{E} 4$ alone than in the vehicles (Figure 4A) as well as in animals from sham group. Figure 4B shows that after treatment with different combinations of steroids, MAP-2 positive area ratio was significantly higher along with the sham group in groups treated by $\mathrm{E} 4$ alone or in combination with $16 \mathrm{mg} / \mathrm{kg} / \mathrm{d}$ P4 compared to the vehicle group. The similar pattern was detected in animals combinedly treated by $5 \mathrm{mg} / \mathrm{kg} / \mathrm{d} \mathrm{E} 4$ with $1.6 \mathrm{mg} / \mathrm{kg} / \mathrm{d} \mathrm{P} 4$ and E2. Treatment with $5 \mathrm{mg} / \mathrm{kg} / \mathrm{d}$ E4 alone or combined either with $1.6 \mathrm{mg} / \mathrm{kg} / \mathrm{P} 4$ and E2 or $16 \mathrm{mg} / \mathrm{kg} / \mathrm{d}$ P4 restored the MAP-2 positive area ratio almost to the sham level. 


\section{Doublecortin and vascular endothelial growth factor double-immunofluorostaining}

Markers for neuro- and vasculogenesis, doublecortine (DCX) and vascular endothelial growth factor (VEGF), respectively, were studied in brain sections (Figure 5). Combined pretreatment with E4 and other steroids resulted in significant upregulation of DCX expression in the DG region (the hippocampus) in $5 \mathrm{mg} /$ $\mathrm{kg} / \mathrm{d}$ E4 and sham groups compared to the vehicles (Table 3 ), whereas the expression of VEGF was significantly upregulated in animals pretreated by $10 \mathrm{mg} / \mathrm{kg} / \mathrm{d} \mathrm{E} 4$ along with $1.6 \mathrm{mg} / \mathrm{kg} / \mathrm{d} \mathrm{P} 4$ and E2 and the sham group compared to the vehicles (Table 3). Furthermore, in the CA1 region significant difference of the DCX expression levels was detected between sham and the vehicle groups, whereas

(A) Hippocampus

(a)

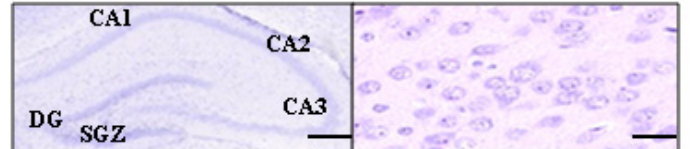

(b)

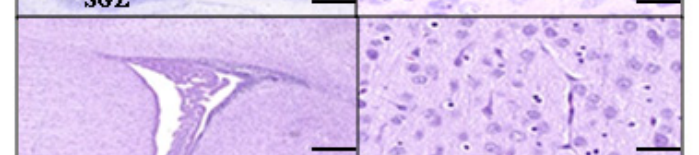

(c)

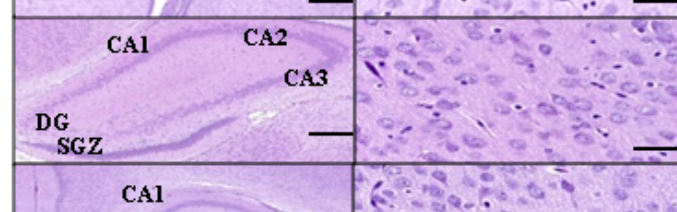

(d)

(e)

(f)

(g)

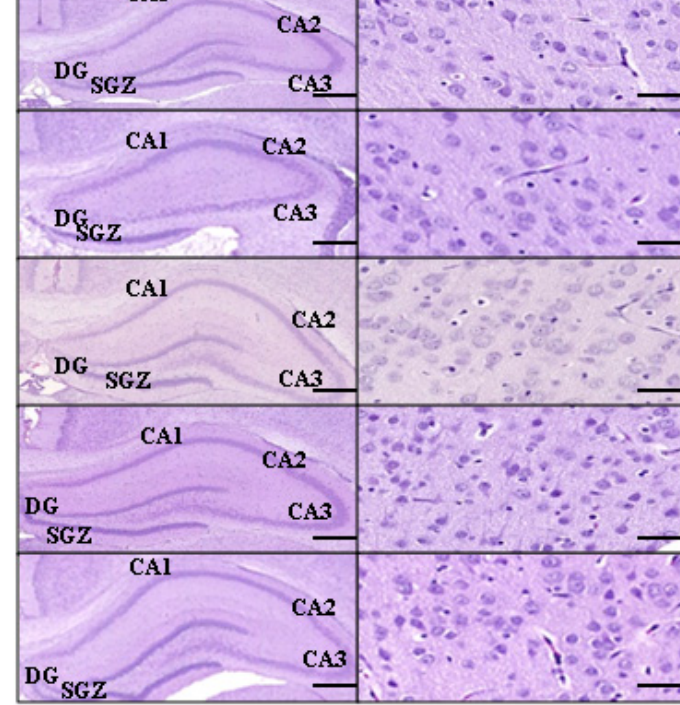

angiogenesis was significantly increased in animals combinedly pretreated by $5 \mathrm{mg} / \mathrm{kg} / \mathrm{d}$ E4 and $16 \mathrm{mg} / \mathrm{kg} / \mathrm{d}$ P4 and the sham group compared to the vehicle group (Table 3). In the CA2/CA3 region expressions of DCX and VEGF were significantly different between sham and the vehicle groups. In the cortex neuro-and angiogenesis were significantly different between the animals from sham group and the animals pretreated by $5 \mathrm{mg} / \mathrm{kg} / \mathrm{d} \mathrm{E} 4$ and $16 \mathrm{mg} / \mathrm{kg} / \mathrm{d}$ P4 compared to animals from the vehicle group (Table 3).

Treatment of animals after HI insult with E4 alone or combined with other steroids resulted in significant upregulation of DCX expression in the hippocampus in animals treated by $5 \mathrm{mg} / \mathrm{kg} / \mathrm{d} \mathrm{E} 4$ alone or with $16 \mathrm{mg} /$ $\mathrm{kg} / \mathrm{d} \mathrm{P} 4$ compared to the vehicle group (Figure 5). Also, sham group showed significantly higher number of DCX positively stained cells than the groups combinedly
(B)

(a)

(b)

(c)

(d)

(e)

(f)

\section{(g)}
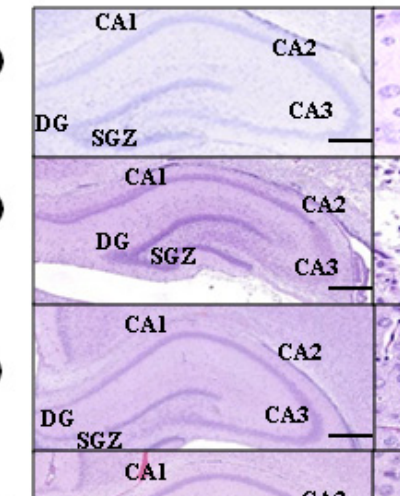

$\mathrm{DG}$

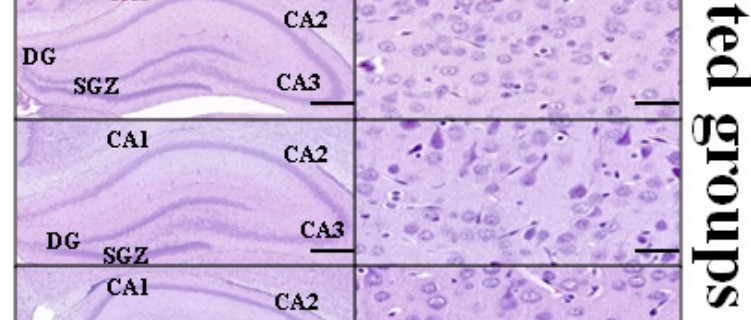

(h)

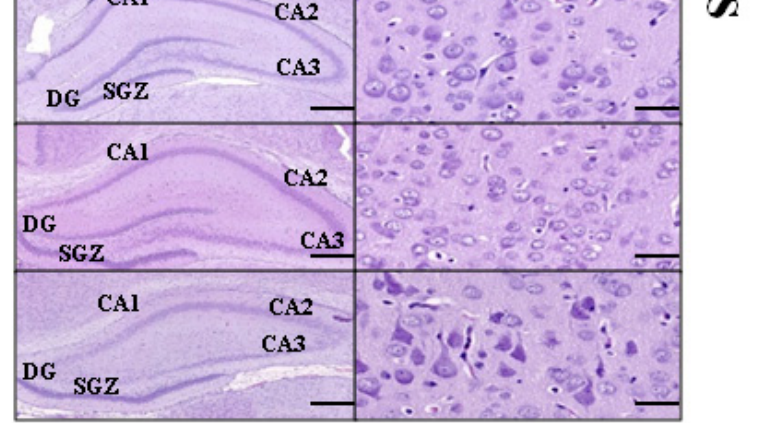

Figure 3: Hematoxylin-eosin staining of the brain coronal sections from rat pups pretreated/treated by $\mathbf{E} 4$ alone or in

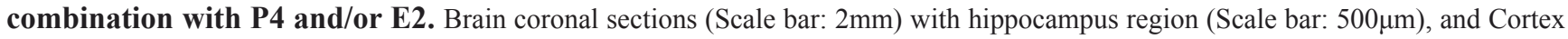
(Scale bar: $100 \mu \mathrm{m}$ ) from pretreated A. and treated B. study groups are shown: sham (a), vehicle (b), $5 \mathrm{mg} / \mathrm{kg} / \mathrm{dayE} 4$ (c), $5 \mathrm{mg} / \mathrm{kg} / \mathrm{day}$ E4+16mg/kg/day P4+136ng $/ \mathrm{kg} /$ day E2 (d), $5 \mathrm{mg} / \mathrm{kg} /$ day E4+136ng/kg/day E2 (e), $10 \mathrm{mg} / \mathrm{kg} /$ day E4 (f), $10 \mathrm{mg} / \mathrm{kg} /$ day E4 $+16 \mathrm{mg} / \mathrm{kg} / \mathrm{day}$ P4 (g), $10 \mathrm{mg} / \mathrm{kg} /$ day E4+136ng/kg/day E2 (h). 
Table 4: Glial fibrillary acidic protein (GFAP) expression in blood serum (pg/ml) of the combinedly pretreated/ treated rat pups.

\begin{tabular}{|c|c|c|c|c|}
\hline \multirow[t]{2}{*}{ Groups } & \multicolumn{2}{|c|}{ Combined Pretreatment } & \multicolumn{2}{|l|}{ Combined Treatment } \\
\hline & $\mathrm{pg} / \mathrm{ml}$ & $\begin{array}{ll}\mathbf{N} & \text { of } \\
\text { samples }\end{array}$ & $\mathrm{pg} / \mathrm{ml}$ & $\mathbf{N}$ of samples \\
\hline Sham & $2393.40 \pm 1454.429 *$ & 8 & $2393.40 \pm 1454.43 \# \#$ & 8 \\
\hline Vehicle & $23915.91 \pm 3158.84 * *$ & 10 & $28901.155 \pm 4480.30$ & 11 \\
\hline $5 \mathrm{mg} / \mathrm{kg} \mathrm{E4}$ & $6220.49 \pm 1763.17$ & 11 & $6380.10 \pm 4062.591$ & 10 \\
\hline $5 \mathrm{mg} / \mathrm{kg} \mathrm{E4}+1.6 \mathrm{mg} / \mathrm{kg} \mathrm{P4}$ & $12548.31 \pm 2280.50$ & 10 & $8146.34 \pm 3596.07$ & 10 \\
\hline $5 \mathrm{mg} / \mathrm{kg} \mathrm{E4+1.6mg/kg} \mathrm{P4+136ng/kg} \mathrm{E2}$ & $1011.42 \pm 55.32$ & 13 & $19226.69 \pm 2559.70$ & 10 \\
\hline $5 \mathrm{mg} / \mathrm{kg} \mathrm{E4}+16 \mathrm{mg} / \mathrm{kg} \mathrm{P4}$ & $5113.67 \pm 1733.57$ & 10 & $25919.72 \pm 4487.50$ & 10 \\
\hline $5 \mathrm{mg} / \mathrm{kg} \mathrm{E4}+16 \mathrm{mg} / \mathrm{kg} \mathrm{P4+136ng/kg} \mathrm{E2}$ & $737.01 \pm 69.82$ & 11 & $17476.73 \pm 2643.53$ & 10 \\
\hline $5 \mathrm{mg} / \mathrm{kg} \mathrm{E4+136ng/kg} \mathrm{E2}$ & $28442.46 \pm 3457.11 * * *$ & 11 & $32354.42 \pm 5946.66$ & 10 \\
\hline $10 \mathrm{mg} / \mathrm{kg} \mathrm{E4}$ & $12413.45 \pm 2243.05$ & 12 & $10806.52 \pm 1915.19 \# \# \#$ & 10 \\
\hline $10 \mathrm{mg} / \mathrm{kg} \mathrm{E4}+1.6 \mathrm{mg} / \mathrm{kg} \mathrm{P4}$ & $27225.88 \pm 8442.88$ & 7 & $18796.20 \pm 4279.45$ & 10 \\
\hline $10 \mathrm{mg} / \mathrm{kg} \mathrm{E} 4+1.6 \mathrm{mg} / \mathrm{kg} \mathrm{P4}+136 \mathrm{ng} / \mathrm{kg} \mathrm{E2}$ & $9672.46 \pm 2461.11$ & 12 & $20470.58 \pm 1468.47$ & 14 \\
\hline $10 \mathrm{mg} / \mathrm{kg} \mathrm{E4}+16 \mathrm{mg} / \mathrm{kg} \mathrm{P4}$ & $12037.18 \pm 3726.66$ & 12 & $15974.26 \pm 2111.42$ & 11 \\
\hline $10 \mathrm{mg} / \mathrm{kg} \mathrm{E4+16mg/kg} \mathrm{P4+136ng/kg} \mathrm{E2}$ & $11202.39 \pm 2765.16$ & 11 & $22202.18 \pm 2624.61$ & 11 \\
\hline $10 \mathrm{mg} / \mathrm{kg} \mathrm{E} 4+136 \mathrm{ng} / \mathrm{kg} \mathrm{E2}$ & $32898.22 \pm 3437.25 \#$ & 11 & $26660.81 \pm 4870.81$ & 10 \\
\hline
\end{tabular}

Significant differences were observed:

in pretreated groups:

*sham vs. vehicle, $10 \mathrm{mg} / \mathrm{kg} / \mathrm{d}$ E4+136ng/kg/d E2, $10 \mathrm{mg} / \mathrm{kg} / \mathrm{d}$ E4+1.6mg/kg/d P4,

** vehicle vs. $5 \mathrm{mg} / \mathrm{kg} / \mathrm{d}$ E4+1.6mg/kg/d P4+136ng/kg/d E2, 5mg/kg/d E4+16mg/kg/d P4+136ng/kg/d E2,

*** 5mg/kg/d E4+136ng/kg/d E2 vs. sham, $5 \mathrm{mg} / \mathrm{kg} / \mathrm{d}$ E4, $5 \mathrm{mg} / \mathrm{kg} / \mathrm{d}$ E4+1.6mg/kg/d P4+136ng/kg/d E2, 5mg/kg/d E4+16mg/ $\mathrm{kg} / \mathrm{d} \mathrm{P} 4,5 \mathrm{mg} / \mathrm{kg} / \mathrm{d}$ E4+16mg/kg/d P4+136ng $/ \mathrm{kg} / \mathrm{d}$ E2,

\#10mg/kg/d E4+136ng/kg/d vs. sham, $10 \mathrm{mg} / \mathrm{kg} / \mathrm{d} \mathrm{E} 4,10 \mathrm{mg} / \mathrm{kg} / \mathrm{d}$ E4+1.6mg/kg/d P4+136ng/kg/d E2, 10mg/kg/d E4+16mg/ $\mathrm{kg} / \mathrm{d} \mathrm{P} 4,10 \mathrm{mg} / \mathrm{kg} / \mathrm{d}$ E4+16mg/kg/d P4+136ng/kg/d E2 ;

in treated groups:

\#\#sham vs. vehicle, $5 \mathrm{mg} / \mathrm{kg} / \mathrm{d}$ E4+136ng/kg/d E2, 10mg/kg/d E4+136ng/kg/d E2,

\#\#\#10mg/kg/d E4 vs. 10mg/kg/d E4+136ng/kg/d E2.

treated either by $5 \mathrm{mg} / \mathrm{kg} / \mathrm{d}$ with $1.6 \mathrm{mg} / \mathrm{kg} / \mathrm{d}$ P4 or $10 \mathrm{mg} /$ $\mathrm{kg} / \mathrm{d}$ E4 with $16 \mathrm{mg} / \mathrm{kg} / \mathrm{d} \mathrm{P} 4$ and E2 as well as groups treated by $\mathrm{E} 4$ in combination with $1.6 \mathrm{mg} / \mathrm{kg} / \mathrm{d} \mathrm{P} 4$ and E2 (Table 3). In the same region the VEGF positively stained cells percentage was significantly increased in the sham operated animals and in groups treated by $5 \mathrm{mg} / \mathrm{kg} / \mathrm{d}$ E4 alone or in combination with $16 \mathrm{mg} / \mathrm{kg} / \mathrm{d}$ P4 than in the vehicle group. Furthermore, in the CA1 region neurogenesis was significantly upregulated in sham group and in animals treated by $5 \mathrm{mg} / \mathrm{kg} / \mathrm{d}$ E4 along with E2 than in the vehicles, whereas angiogenesis was significantly upregulated in sham group and in animals treated by $10 \mathrm{mg} / \mathrm{kg} / \mathrm{d}$ E4 with $1.6 \mathrm{mg} / \mathrm{kg} / \mathrm{d} \mathrm{P} 4$ compared to the vehicles (Table 3 ). In the $\mathrm{CA} 2 / \mathrm{CA} 3$ region significant differences in DCX expression was detected between sham group, the animals treated by $10 \mathrm{mg} / \mathrm{kg} / \mathrm{d}$ E4 with $1.6 \mathrm{mg} /$ $\mathrm{kg} / \mathrm{d} \mathrm{P} 4$ and the vehicles as well as between sham group, the animals treated by $5 \mathrm{mg} / \mathrm{kg} / \mathrm{d}$ E4 with $16 \mathrm{mg} / \mathrm{kg} / \mathrm{d} \mathrm{P} 4$ and the group treated by $5 \mathrm{mg} / \mathrm{kg} / \mathrm{d}$ E4 alone (Table 3 ). In the same region VEGF was significantly expressed in sham group than in the vehicles. In the cortex neuro- and angiogenesis were significantly upregulated in sham group compared to the vehicle group. In general, combination of E4 with E2 resulted in low DCX and VEGF expression levels in the cortex.

\section{Blood serum glial fibrillary acidic protein (GFAP) expression}

Glial fibrillary acidic protein (GFAP) expression, as brain damage marker, was evaluated in blood sera by using ELISA. As shown in Table 4, combined pretreatment by E4 with P4 and/or E2 resulted in significant difference of GFAP concentration levels between the sham-operated group and the animals pretreated by the vehicle or by $10 \mathrm{mg} / \mathrm{kg} / \mathrm{d}$ E4 in combination either with E2 or $1.6 \mathrm{mg} /$ $\mathrm{kg} / \mathrm{d}$ P4. Animals pretreated by $5 \mathrm{mg} / \mathrm{kg} / \mathrm{d}$ E4 with E2 and P4 had significantly lower level of GFAP protein than the vehicle group. Significant downregulation of GFAP concentration was also observed in animals pretreated either by $5 \mathrm{mg} / \mathrm{kg} / \mathrm{d} \mathrm{E} 4$ alone or in combination with 
different doses of P4 and E2 or combined with $16 \mathrm{mg}$ / $\mathrm{kg} / \mathrm{d} \mathrm{P} 4$ and in sham group than in animals pretreated by $5 \mathrm{mg} / \mathrm{kg} / \mathrm{d}$ E4 and E2 (Table 4). The same pattern of GFAP concentration differences were observed between groups pretreated by $10 \mathrm{mg} / \mathrm{kg} / \mathrm{d} \mathrm{E} 4$ alone or in combination with different doses of P4 and E2 or with $16 \mathrm{mg} / \mathrm{kg} / \mathrm{d}$ P4 than in animals pretreated by $10 \mathrm{mg} / \mathrm{kg} / \mathrm{d}$ E4 and E2 (Table 4).

Treatment by E4 with $\mathrm{P} 4$ and/or E2 resulted in significant decrease of GFAP protein concentration in 10 $\mathrm{mg} / \mathrm{kg} / \mathrm{d} \mathrm{E} 4$ and the sham groups than in animals treated by combination of $10 \mathrm{mg} / \mathrm{kg} / \mathrm{d} \mathrm{E} 4$ and E2. Also, the shamoperated group had significantly lower concentration of GFAP than the vehicle group and animals treated by E4 and E2. In both pretreated and treated groups the combination of E4 and E2 showed significantly higher levels of GFAP, suggesting a negative cooperativity of these steroids upon cell survival.

\section{DISCUSSION}

Our results evaluate the efficacy of E4 administration alone or in combination with P4 and/or E2 for neuroprotection in a 7-day-old rat pups model of hypoxic-ischemic brain damage. Neurogenesis in humans starts around day 33 of the embryonal development and by $8-9$ wks of gestation the cortical plate is usually formed [53]. Both estrogen receptors: $\alpha(E R \alpha)$ and $\beta(E R \beta)$, are expressed in the

\section{(A)}

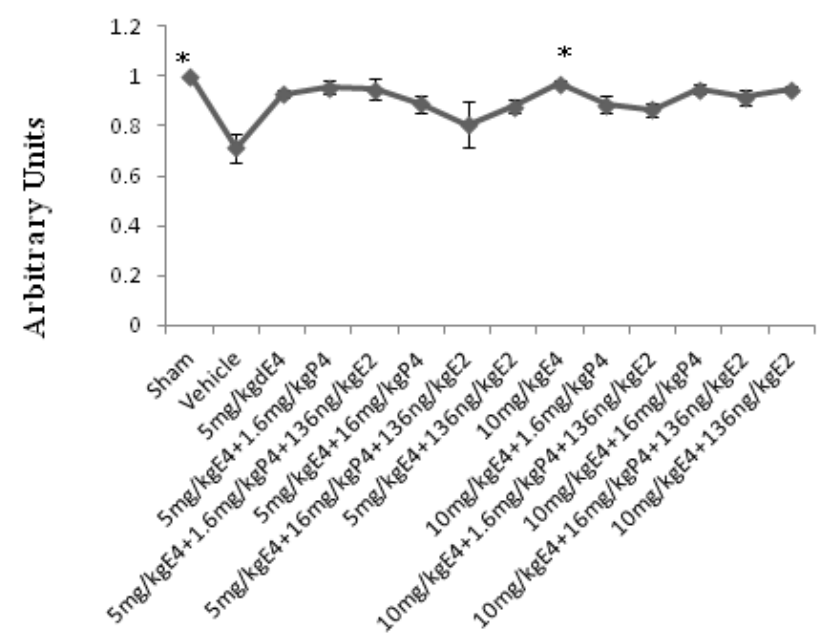

human cortex and hippocampus during neurodevelopment. $\mathrm{ER} \alpha$, detected by 9 weeks of gestation, plausibly has importance for the early neurodevelopment, whereas ER $\beta$ might have importance for later processes, such is corticogenesis [54]. In rats, estrogen receptors present in developing brain as well as in adults brains mainly in the hippocampus $[55,56]$ with a significant binding properties at postnatal day 4 (P4) which declines to adult levels by P15 $[57,58]$. The expression of ER $\alpha$ mRNA in the neonatal cortex and/or olfactory bulb and the cerebellum supports the notion that $\mathrm{ER} \alpha$ might be connected to cellular differentiation as well as to sexual differentiation of the brain during neurodevelopment $[59,60]$. It might, in addition, have a role in estradiol-dependent protection against delayed cell death [61], and as it was recently shown, in genetically modified animals with middle cerebral artery occlusion (MCAO) the ER $\alpha$ might have importance in neuroprotection supported by estrogens [62]. Estrogens neuroprotective properties are realized through different pathways, for example, estrogens may increase the astrocyte's possibility to absorbe glutamate and like that prevent the glutamate toxicity-mediated neuronal loss $[63,64]$. Estrogens also have an importance in suppression of neuroinflammation [65], and activation ERK pathways which are necessary for the maintenance of neuritic arborisation and neuronal morphology [66]. Recent studies proved that the neuroprotective actions of estrogens also depend on their strong antioxidant specifications and positively correlate with the number

\section{(B)}

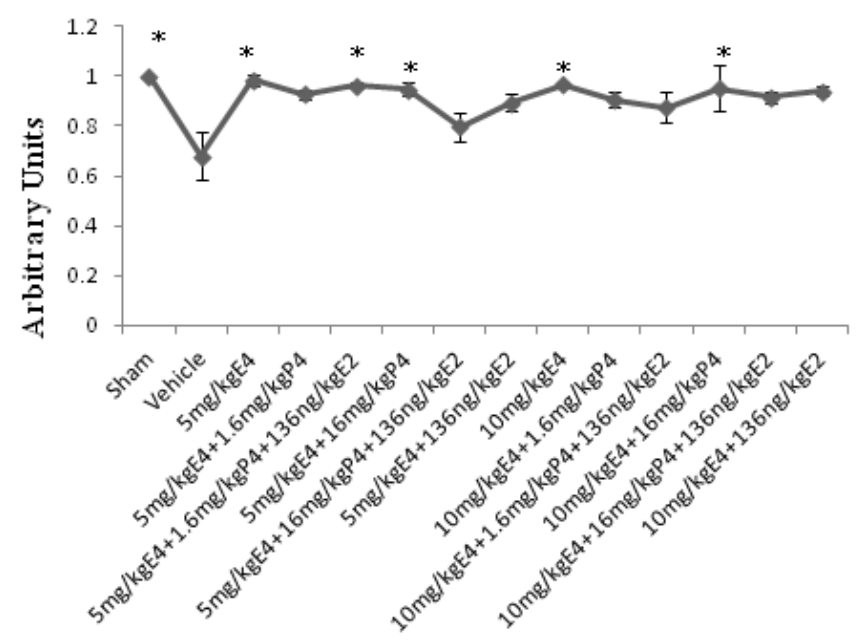

Figure 4: MAP-2 staining of brain coronal sections from rat pups pretreated/treated by E4 alone or in combination with P4 and/or E2. For evaluation of gray matter loss MAP2 staining was performed. A. Among pretreated groups the MAP2-positively stained area ratio was significantly upregulated in animals pretreated by $10 \mathrm{mg} / \mathrm{kg} / \mathrm{day}$ E4 alone than in the vehicles as well as in animals from sham group. B. After treatment with different combinations of steroids, MAP-2 positive area ratio was significantly higher along with the sham group in groups treated by $5 \mathrm{mg} / \mathrm{kg} /$ day or $10 \mathrm{mg} / \mathrm{kg} /$ day E4 alone or in combination with $16 \mathrm{mg} / \mathrm{kg} /$ day P4 compared to the vehicle group. The similar pattern was observed in animals combinedly treated by $5 \mathrm{mg} / \mathrm{kg} / \mathrm{day}$ E4 with $1.6 \mathrm{mg} / \mathrm{kg} / \mathrm{day} \mathrm{P} 4 \mathrm{and} 136 \mathrm{ng} / \mathrm{kg} / \mathrm{day}$ E2. 10 samples from each group were analyzed. The ratio of the MAP2 positive area in sham operated animals was considered as 1.0 by default. All measurements are expressed as mean \pm SEM. ${ }^{*} p \leq 0.05$. 
of the phenolic moiety in their structure; existance of the free phenolic $\mathrm{OH}$ group is absolutely important for protection against oxidative stress [67]. The highest number of the free phenolic $\mathrm{OH}$ groups among estrogens is in E4 suggesting the strong antioxidant effects of this compound. Much research has been done to study the mitochondria as a primary target for estrogen-mediated pathways [68-72]. Furthermore, estrogens may increase aerobic glycolysis, generation ATP along with the increase of the $\mathrm{Ca} 2+$ load tolerance leading to the antioxidant defense [73]. As it was already demonstrated, estrogen receptor activation offers neuroprotection, in part, through transcriptional mechanisms affecting the apoptotic cascade including BCl2, caspases and Apaf-1 [31, 74-76] like that limiting the cell death. Another way for estrogen-mediated neuroprotection might be connected to the direct activation of pathways involving MAP-kinase by ER [77].

On the other hand, the rat forebrain expresses high levels of progesterone receptors (PR) as early as E17-E18 in regions with important cognitive, motor and visual functions, pointing out the importance of the hippocampus in establishment of early cortical circuitry.
P4 neuroprotective effects involve the activation of a number of pathways that influence inflammatory and oxidative mechanisms, and the repair processes that follow in response to injury. In the adult rat brain, the upregulation of nitric oxide synthase-2 (NOS-2), involved in production of nitric oxide free radicals, and pro-inflammatory IL- $1 \beta$ after ischemic events caused by MCAO is inhibited by progesterone treatment [78]. P4 also reduces the proliferation of reactive astrocytes, and inflammatory prostaglandin synthesis further leading to the reduction of edema and the blood-brain barrier leakage in adults after traumatic brain injury [16, 79]. Also, it influences post-ischemic synaptogenesis in the specific region of the hippocampus such is CA1 [80]. P4 is linked to activation of ERK, MAPK and PI3K/Akt pathways that are neuroprotective against glutamate-induced cell death, having inhibitory effect on neuronal apoptosis leading to the alleviation of HIE $[26,41]$. P4 may induce a neuroprotective effect by upregulating expression of brain-derived neurotrophic factor (BDNF) which is a nerve growth factor that promotes neuron survival and formation of synapses $[26,81]$. It was demonstrated that
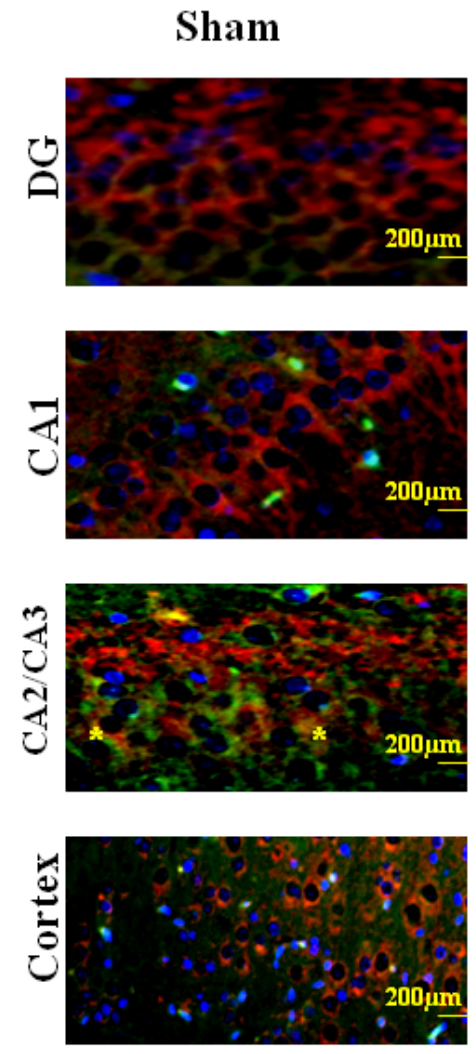

\section{Combined}

Pretreatment
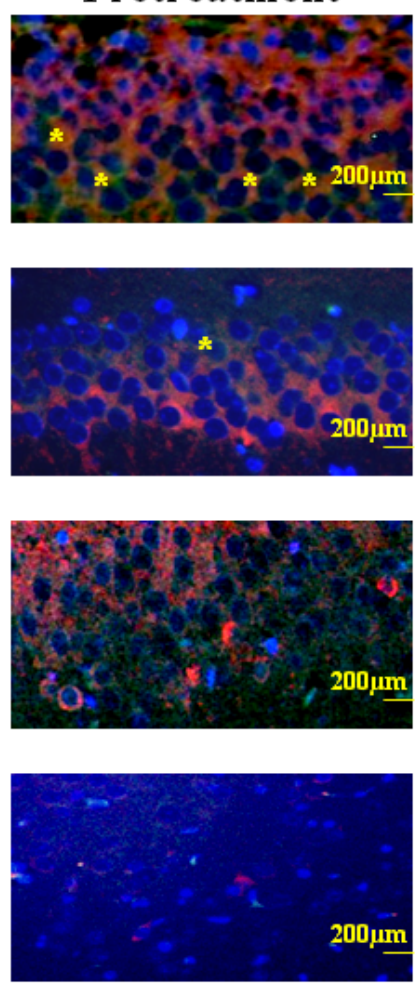

\section{Combined}

\section{Treatment}
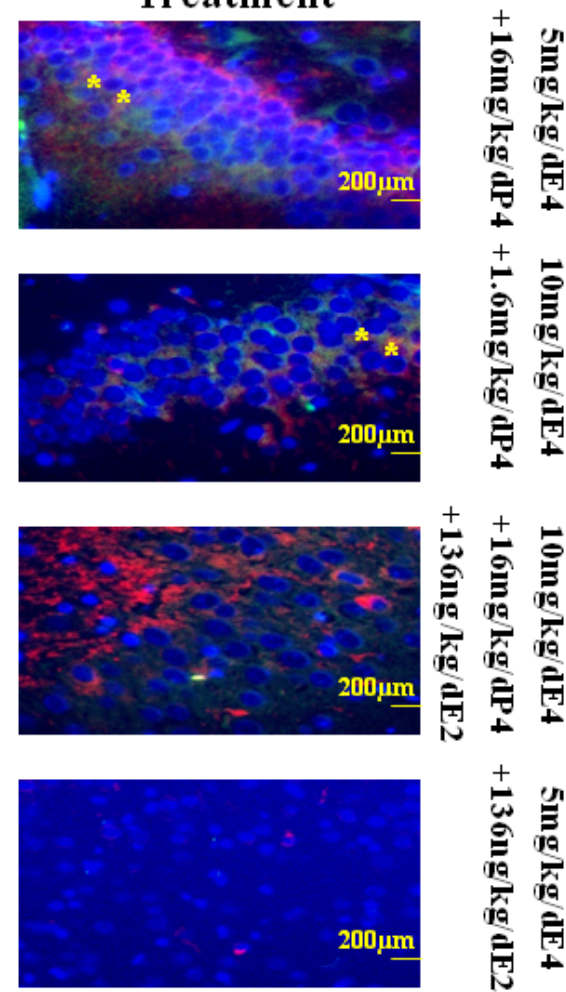

Figure 5: Representative views of double-labeled immunofluorescent sections from different regions of the hippocampus and the cortex from groups pretreated/treated with E4 alone or in combination with $\mathbf{P 4}$ and/or E2. To determine the localization and expression of DCX and VEGF in different regions of the hippocampus and the cortex the double immunofluorescent staining was performed. Red cells denote the DCX positively stained cells, whereas green cells denote the VEGF positively stained cells. Asterisks indicate co-localization of DCX and VEGF positively stained cells. Scale bar: $200 \mu \mathrm{m}$. 
P4 has a promyelinating effect by promoting increase of myelin basic protein expression (MBP) [82]. Furthermore, it might upregulate the well-known inhibitory transmitter GABAa and may reduce the apoptosis by downregulation of NFкB [83-85]. Taken together, P4 along with E2 plays a critical role in neuronal developmental processes not only in prenatal period but in adulthood as well [86, 87].

Recent studies already demonstrated possible link between E4, E2 and P4 in the CNS. $5 \mathrm{mg} / \mathrm{kg} /$ day E4 increased allopregnanolone (3-hydroxy-5-pregnan20-one (AP), a well-known metabolite of $\mathrm{P} 4$, rates in different brain regions and in the serum of ovariectomized (OVX) animals. However, the presence of E2 abolished these effects mediated by E4 [34]. Our previous studies demonstrated that the concomitant exposure to E2 and E4 in vitro and in vivo resulted in a partially antagonized effect of E4 on the proliferation induced by E2 on HBE cells and on mammary gland growth [88]. These observations are in concert with our present results connected to the concomitant use of $\mathrm{E} 4$ and $\mathrm{E} 2$ : neither in vitro nor in vivo combinations of E4 and E2 (except the combination of the highest dose of E4 with E2 in vitro) showed any significant positive result compared to the vehicle group suggesting that E4 and E2 possibly antagonize each other effects.

According to some studies, P4 might prevent estradiol-induced dendritic spine formation in cultured hippocampal cells by antagonizing the effect of E2 on hippocampal spine density or even contribute to the loss of hippocampal spines and spine synapses noted across the estrous cycle, though during the first $6 \mathrm{~h}$ of $\mathrm{P} 4 \mathrm{use}$, it

(A)

\section{Neuroprotective effect (pretreatment by neurosteroids)}
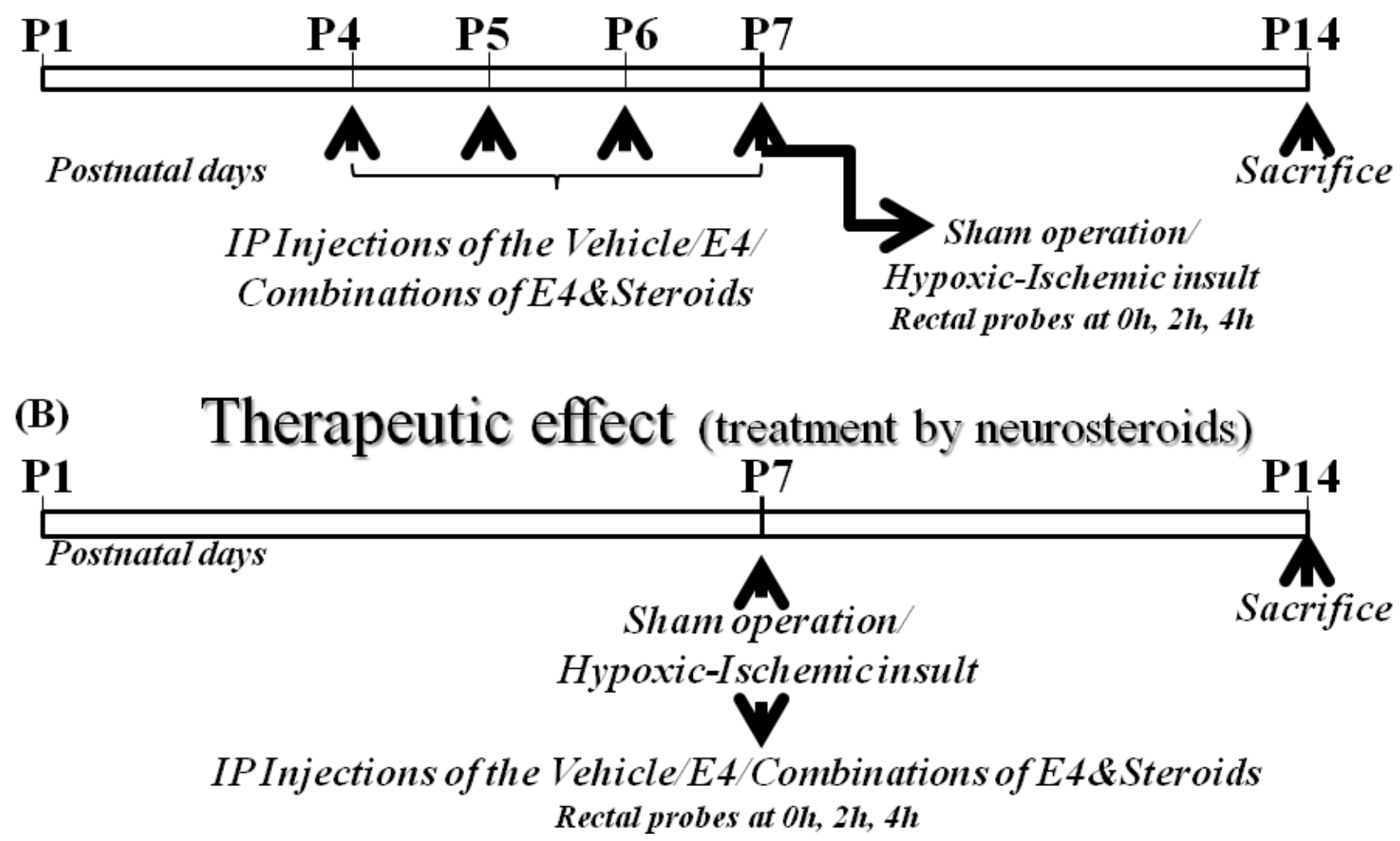

Figure 6: Schematic representation of in vivo studies. A. E4 pretreatment (neuroprotective effect). Newborn rat pups at P4 were assigned to: sham group (neither vehicle nor E4/steroids were applied), vehicle group or groups of animals pretreated either by $5 \mathrm{mg} / \mathrm{kg} / \mathrm{d}$ $\mathrm{E} 4$ and $10 \mathrm{mg} / \mathrm{kg} / \mathrm{d}$ E4 alone or in combination either with $1.6 \mathrm{mg} / \mathrm{kg} /$ day P4 and $/$ or $136 \mathrm{ng} / \mathrm{kg} /$ day E2 or with $16 \mathrm{mg} / \mathrm{kg} / \mathrm{day} \mathrm{P4} \mathrm{and} / \mathrm{or} 136 \mathrm{ng} /$ $\mathrm{kg}$ /day E2. From P4 to P7 inclusive, the rat pups were administered ip either vehicle or E4 alone or E4 combined with other steroids or neither by vehicle nor by other compounds (sham group). At P7, animals from the vehicle and steroid groups were subjected to hypoxicischemic (HI) insult. The sham group passed through anesthesia and skin incision but without HI insult or injections. Rat pups were sacrificed at P14. B. E4 treatment (therapeutic effect). Newborn rat pups at P7 were assigned to: sham group (neither vehicle nor E4/steroids were applied), vehicle treated group or groups of animals pretreated either by $5 \mathrm{mg} / \mathrm{kg} / \mathrm{d} \mathrm{E} 4$ and $10 \mathrm{mg} / \mathrm{kg} / \mathrm{d} \mathrm{E} 4$ alone or in combination either with $1.6 \mathrm{mg} / \mathrm{kg} /$ day P4 and/or 136ng/kg/day E2 or with $16 \mathrm{mg} / \mathrm{kg} /$ day P4 and $/$ or $136 \mathrm{ng} / \mathrm{kg} / \mathrm{day}$ E2. At P7, animals from the vehicle and steroid groups passed through hypoxic-ischemic (HI) procedures. Upon retrieval from hypoxia chamber rat pups were administered ip either vehicle or one of combinations of E4, P4 and/or E2. The sham group went through anesthesia and skin incision but without HI insult or injections. Rat pups were sacrificed a tP14. 
increases the hippocampal dendritic spine density [89-91]. In our present studies combined use of E4, P4 and E2 in vitro showed significant downregulation of LDH activity and the higher cell survival rate than the combination of E4 and E2 or even the single use of E4. These results were similar to those obtained upon the combined use of E4 and P4 suggesting that combined use of E4 and P4 potentiates each other's effects and somehow neutralizes the antagonizing effect of E4 on E2 when 3 compounds are used together. In vivo studies showed that some combinations of E4 with P4 and or E2 might affect the body temperature, and the combination of E4 with P4 may affect positively the body weight, but animals pretreated by combination of E4 with P4 and E2 have significantly higher brain/body ratio suggesting that combined use of E4, P4 and E2 may result in disproportional development. Only the single use of E4 after HI insult had significant effect on brain weight without affecting the brain/body ratio. E4 alone and some combinations of E4, P4 and/or E2 had positive effects on intact cells number in different hippocampal regions and the cortex, though in pretreated groups the number of intact cells was significantly upregulated in the DG region when $\mathrm{E} 4$ was used alone rather than combined with $\mathrm{P} 4$ and/or E2.

The early gray matter was significantly preserved in pretreated groups with single use of E4, whereas in combinedly treated groups the MAP-2 staining was significantly upregulated when E4 was used alone or combined with P4 and/or E2. As it was shown from our previous study [33], E4 positively affected the expression of a marker of neurogenesis (DCX), suggesting upregulation of neurogenesis, possibly through estrogen receptors. Our current study is in concert with the previous one and, moreover, it shows that combined use of E4 with P4 also affects neurogenesis suggesting that neurogenesis might be upregulated not only through estrogen receptors but through progesterone receptors as well, though involvement of some other mechanisms is also plausible. As it was shown recently, VEGF, an angiogenic protein, has impressive neurotrophic and neuroprotective effects by stimulating neurogenesis in vitro and in vivo in the subventricular zone (SVZ) and the subgranular zone (SGZ) of the brain [92] by promoting proliferation of cortical neuron precursors through regulation of E2F expression (the family of transcription factors, a key regulator of the cell cycle machinery) [93]. On the other hand, there is an important correlation between the neuronal VEGF expression and angiogenesis in immature rat brain $[92,94]$. Taken together, a mechanism linked to the neurogenesis after combined use of E4 and P4 might be also connected to elevated expression of VEGF from neuronal cells.

Some recent clinical investigations showed that the serum GFAP levels during the first week of life are increased in neonates suffering from HIE and the severity corresponds very well with MRI findings [95, 96].
Thus, GFAP might be used as marker for brain damage prediction and could help detect neonates with moderate or severe HIE. GFAP might be used as prognostic marker for evaluation of treatment efficacy as well $[95,96]$. In our present study GFAP was significantly downregulated either by single dose of E4 or by its combination with P4 and E2. Evaluation of positive effects of different combinations of E4 with $\mathrm{P} 4$ and/or E2 in both in vivo models by the number of experimental benefits and the importance for each region of the brain we studied leads us to the conclusion that an important results are shown either by combination of $5 \mathrm{mg} / \mathrm{kg} / \mathrm{d} \mathrm{E} 4$ with $16 \mathrm{mg} / \mathrm{kg} / \mathrm{d} \mathrm{P} 4$ or by the use of $10 \mathrm{mg} / \mathrm{kg} / \mathrm{d} \mathrm{E} 4$ alone.

In conclusion, E4 is an estrogen with SERM properties related to its dual action of agonist on the nuclear ER $\alpha$ and the antagonist activity on the membrane $\mathrm{ER} \alpha$, whereas E2, in contrast, activates both forms of ER $\alpha$ [36]. Our data further confirms the potential antagonistic activity of E4 on E2 initiated activities. We speculate that combined use of E4 does not have any priority over the isolated use of E4. One limitation of our study might be the fact that we did not compare our results with the single doses of P4 or E2, but our aim was to show that E4, a natural human estrogen solely produced in large quantities during human pregnancy [32], could be a safe and efficient candidate for treatment of early brain damage in newborns. The high selectivity of E4 and a lack of impact on coagulation and the liver [97] suggests a low risk of unexpected side-effects. Taken together, single use of E4 has enough benefits and potency to become an important safe substance for treatment of HIE.

\section{MATERIALS AND METHODS}

\section{In vitro studies}

\section{Preparation of primary hippocampal neuronal cultures}

We prepared primary hippocampal neuronal cultures from newborn (P0) Sprague-Dawley (SD) rat pups brains according to the recently published protocols $[98,99]$ which we have used in our previous study [33]. Briefly, brains were dissected to separate hippocampus region. Hippocampi were separated in dissection medium consisting of Hanks Balanced Salt Solution (HBSS), Invitrogen, Gent, Belgium) supplemented with Sodium Pyruvate (100x) (Invitrogen, Gent, Belgium), Glucose (Sigma-Aldrich,St. Louis, MO, USA), and HEPES buffer (10mM) (Sigma-Aldrich, St. Louis, MO, USA)). After washing the tissue was placed in fresh dissection medium with $2.5 \%$ trypsin solution (Invitrogen, Gent, Belgium), and further incubated in a 5\% CO2, 95\% air atmosphere 
at $37^{\circ} \mathrm{C}$ for $20 \mathrm{~min}$. After adding DNase solution (SigmaAldrich, St. Louis, Mo, USA), hippocampi were incubated at room temperature for $5 \mathrm{~min}$ in fresh dissectin medium. Hippocampi were resuspended in $2.5 \mathrm{ml}$ of plating medium consisting of Minimal Essential Medium (MEM) with Earle's salts (Invitrogen, Gent, Belgium), supplemented with $10 \%$ of fetal bovine serum (FBS) (Invitrogen, Gent, Belgium), Glucose (Invitrogen, Gent, Belgium), Sodium Pyruvate (Invitrogen, Gent, Belgium), GlutaMax-Isupplement (Invitrogen, Gent, Beligum), and Penicillin/ Strepromycin (100x) (Invitrogen, Gent, Belgium). Hippocampi were dissociated and the cell viability was evaluated. The dissociated cells were plated on polyL-lysine coated 24 -well $\left(5 \times 10^{4}\right.$ Cells/well $)$ or $96-w e l l$ $\left(5 \times 10^{3}\right.$ cells/well $)$ culture plates. Coating Poly-L-Lysine solution was prepared from Poly-L-lysine powder (SigmaAldrich, St. Louis, MO, USA). Cultures were incubated in a humidified $5 \% \mathrm{CO} 2 / 95 \%$ air atmosphere at $37 \mathrm{C}^{\circ}$ in maintenance medium consisting of Neurobasal medium (Invitrogen, Gent, Belgium), containing of supplement B-27 (50x) (Invitrogen, Gent, Belgium), GlutaMax-Isupplement (Invitrogen, Gent, Belgium), and penicillin/ Streptomycin (100x) (Invitrogen, Gent, Belgium). Cytosine arabinosidase (Ara-C) (Sigma-Aldrich, St. Louis, MO, USA) was added to the maintenance media $48 \mathrm{~h}$ later after plating of the cells during $24 \mathrm{~h}$. Upon changing the culture medium, the cultures were incubated for additional 3-4 days prior to use.

\section{Cell culture stimulation with $\mathrm{H202}, \mathrm{E} 4$ alone or in combination either with $\mathrm{E} 2$ and/orP4}

To define the concentrations of E2 (Sigma-Aldrich, St. Louis, MI, USA) and P4 (Sigma-Aldrich, St. Louis, MI, USA) with antioxidative and neuroprotective properties on primary hippocampal cell cultures prepared from newborn rat pups, at day 7 after plating cells, cultures were treated with $100 \mu \mathrm{M}$ of $\mathrm{H} 202$ for 30min (Merck KGaA, Darmstadt, Germany) and then with different concentrations of E2 or $\mathrm{P} 4$ from $1 \mathrm{nM}$ to $1 \mathrm{mM}$ for $1 \mathrm{~h}$. Cell cultures treated only with $100 \mu \mathrm{M}$ of $\mathrm{H} 202$ for $1 \mathrm{~h} 30$ min were used as controls (data not shown). Successful concentrations (100nM of E2 and 1mM of P4) were further considered for combination studies with E4 (Pantarhei Bioscience, Zeist, The Netherlands) in primary hippocampal cell cultures. We used the same concentrations of E4 as in our previous in vitro studies [33]. To study an antioxidative and neuroprotective effects of E4 in combination with other steroids on primary hippocampal cell cultures at day 7 in vitro (DIV), they were stimulated with $100 \mu \mathrm{M}$ of H202 for 30 min followed by treatment for $1 \mathrm{~h}$ either with $650 \mu \mathrm{M}, 3.25 \mathrm{mM}$ and $6.5 \mathrm{mM} \mathrm{E} 4$ alone or in combination with 100nM E2 and/or 1mM P4 as followed: E4+100nM E2, E4+1mM P4, E4+100nM E2+1mM P4. Cell cultures treated only with $100 \mu \mathrm{M}$ of $\mathrm{H} 202$ for $1 \mathrm{~h} 30$ min were used as controls. Supernatants were subjected to the LDH activity and the cells viability assays. The rest of the cell cultures were subjected to the cell viability assay.

\section{Evaluation of lactate dehydrogenase (LDH) activity}

To evaluate the existance of oxidative stress and expression of $\mathrm{LDH}$ in primary hippocampal cell cultures stimulated by different concentrations of E4 alone or in combination with other steroids after experimental oxidative stress, a commercial LDH assay kit was used (Abcam Inc, Cambridge, MA, USA) as previously [33]. This colorimetric method for quantification of $\mathrm{LDH}$ activity transforms NAD to NADH. All procedures were performed in accordance to the manufacturer's protocol. Each condition was repeated 4-7 times.

\section{Cell viability assay}

To evaluate the cell viability, the primary hippocampal cell cultures were stimulated by $100 \mu \mathrm{M}$ of H202 and followed by treatment with few doses of E4 alone or in combination with other steroids. A commercial Cell Titer $96^{\circledR}$ aqueous one solution cell proliferation assay kit was used (Promega Corporation, Madison, WI, USA) as previously [33]. Each condition was repeated 3-6 times.

\section{In vivo studies}

We obtained SD pregnant rats from Janvier (France). After delivery, the newborn pups were reared with their dams at $25^{\circ} \mathrm{C}$. All experimental procedures were supported by the University of Liege (Belgium) Ethical Committee. The steroids used for in vivo studies were dissolved in absolute Ethanol $(\mathrm{EtOH})$ and further diluted at a final concentration of $\mathrm{EtOH} 10 \%$ in sesame oil. An equal volume ( $5 \mu \mathrm{l} / \mathrm{g}$ body weight) was injected intraperitoneally (ip) into the pups from study groups. The vehicle group animals were ip injected a sesame oil containing 10\% EtOH. No injections were performed in sham group.

\section{Neuroprotective (pretreatment) effect of E4 alone or in combination with $\mathrm{P} 4$ and/or E2 (Figure 6A)}

To compare the neuroprotective effect of E4 alone or E4 in combination with E2 and/or P4 the rat pups from P4 were designated different groups: sham group $(n=12)$ (without any kind of pretreatment), vehicle group $(n=17)$, $5 \mathrm{mg} / \mathrm{kg} / \mathrm{d} \mathrm{E} 4(n=13), 10 \mathrm{mg} / \mathrm{kg} / \mathrm{d}$ E4 $(n=12), 5 \mathrm{mg} / \mathrm{kg} / \mathrm{d}$ $\mathrm{E} 4+1.6 \mathrm{mg} / \mathrm{kg} / \mathrm{d}$ P4 $(n=11), 10 \mathrm{mg} / \mathrm{kg} / \mathrm{d} \mathrm{E} 4+1.6 \mathrm{mg} / \mathrm{kg} / \mathrm{d}$ $\mathrm{P} 4(n=11), 5 \mathrm{mg} / \mathrm{kg} / \mathrm{dE} 4+16 \mathrm{mg} / \mathrm{kg} / \mathrm{d} \mathrm{P} 4(n=11), 10 \mathrm{mg} /$ $\mathrm{kg} / \mathrm{d} \mathrm{E} 4+16 \mathrm{mg} / \mathrm{kg} / \mathrm{d}$ P4 ( $n=11), 5 \mathrm{mg} / \mathrm{kg} / \mathrm{d} \mathrm{E} 4+136 \mathrm{ng} / \mathrm{kg} / \mathrm{d}$ 
E2 $(n=11), 10 \mathrm{mg} / \mathrm{kg} / \mathrm{d} \mathrm{E} 4+136 \mathrm{ng} / \mathrm{kg} / \mathrm{d} \mathrm{E} 2(n=11), 5 \mathrm{mg} /$ $\mathrm{kg} / \mathrm{d} \mathrm{E} 4+1.6 \mathrm{mg} / \mathrm{kg} / \mathrm{d}$ P4+136ng/kg/d E2 ( $n=13), 10 \mathrm{mg} /$ $\mathrm{kg} / \mathrm{d}$ E4+1.6mg/kg/d P4+136ng/kg/d E2 $(n=16), 5 \mathrm{mg} /$ $\mathrm{kg} / \mathrm{d} \mathrm{E} 4+16 \mathrm{mg} / \mathrm{kg} / \mathrm{d} \mathrm{P} 4+136 \mathrm{ng} / \mathrm{kg} / \mathrm{d}$ E2 $(n=11), 10 \mathrm{mg} /$ $\mathrm{kg} / \mathrm{d}$ E4+16 mg/kg/d P4+136ng/kg/d E2 $(n=13)$ groups according to the group assignment. Estetrol concentrations $5 \mathrm{mg} / \mathrm{kg} / \mathrm{d}$ and $10 \mathrm{mg} / \mathrm{kg} / \mathrm{d}$ were the most successful doses used in our previous studies [33]. A model of hypoxiaischemia in an immature rats was used at P7 [42] with slight modifications as in our previous study [33]. Briefly, $30 \mathrm{~min}$ after the last injection either of E4 alone or E4 combined with P4 and/or E2 or vehicle, animals passed through anesthesia with isoflurane (induction 3.0\%; maintenance, $1.50 \%$ ), and the left common carotid artery was double ligated and severed. The pups recovered for $1 \mathrm{~h}$ with their dams. Then the pups passed through hypoxia in the special humidified hypoxic in vivo chamber (CoyLab, Grass Lake, MI, USA). For the first 20 min hypoxia was produced by decreasing oxygen concentration (from $11 \%$ to $8 \%$ ) balanced with nitrogen, followed by hypoxia at a concentration of $8 \%$ oxygen balanced with $92 \%$ nitrogen for another $35 \mathrm{~min}$ at $37^{\circ} \mathrm{C}$ as previously described [33]. The sham group also passed through operation but the carotid artery was neither ligated nor severed and the pups were not exposed to hypoxia. Rat pups were euthanized at P14 (Figure 6A).

\section{Therapeutic (treatment) effect of E4 alone or E4 combined with E2 and/or P4 (Figure 6B)}

To compare the therapeutic effect of E4 alone or E4 in combination with E2 and/or P4 after hypoxic-ischemic insult at P7, pups were designated to one of groups: sham group $(n=12)$, vehicle $(n=15), 5 \mathrm{mg} / \mathrm{kg} / \mathrm{d} \mathrm{E} 4(n=11)$, $10 \mathrm{mg} / \mathrm{kg} / \mathrm{d}$ E4 $(n=11), 5 \mathrm{mg} / \mathrm{kg} / \mathrm{d}$ E4+1.6mg $/ \mathrm{kg} / \mathrm{d}$ P4 $(n=11), 10 \mathrm{mg} / \mathrm{kg} / \mathrm{d}$ E4+1.6mg $/ \mathrm{kg} / \mathrm{d}$ P4 $(n=11), 5 \mathrm{mg} /$ $\mathrm{kg} / \mathrm{d} \mathrm{E} 4+16 \mathrm{mg} / \mathrm{kg} / \mathrm{d}$ P4 $(n=11), 10 \mathrm{mg} / \mathrm{kg} / \mathrm{d} \mathrm{E} 4+16 \mathrm{mg} /$ $\mathrm{kg} / \mathrm{d}$ P4 $(n=13), 5 \mathrm{mg} / \mathrm{kg} / \mathrm{d}$ E4+136ng/kg/d E2 $(n=$ $11), 10 \mathrm{mg} / \mathrm{kg} / \mathrm{d} \mathrm{E} 4+136 \mathrm{ng} / \mathrm{kg} / \mathrm{d} \mathrm{E} 2(n=11), 5 \mathrm{mg} / \mathrm{kg} / \mathrm{d}$ $\mathrm{E} 4+1.6 \mathrm{mg} / \mathrm{kg} / \mathrm{d} \mathrm{P} 4+136 \mathrm{ng} / \mathrm{kg} / \mathrm{d}$ E2 $(n=12), 10 \mathrm{mg} / \mathrm{kg} / \mathrm{d}$ $\mathrm{E} 4+1.6 \mathrm{mg} / \mathrm{kg} /$ day P4+136ng/kg/d E2 $(n=11), 5 \mathrm{mg} /$ $\mathrm{kg} / \mathrm{d}$ E4+16mg/ kg/d P4+136ng/kg/d E2 ( $n=11), 10 \mathrm{mg} /$ $\mathrm{kg} / \mathrm{d} \mathrm{E} 4+16 \mathrm{mg} / \mathrm{kg} / \mathrm{d} \mathrm{P} 4+136 \mathrm{ng} / \mathrm{kg} / \mathrm{d}$ E2 $(n=12)$ groups. Estetrol concentrations $5 \mathrm{mg} / \mathrm{kg} / \mathrm{d}$ and $10 \mathrm{mg} / \mathrm{kg} / \mathrm{d}$ were the most successful doses used in our previous studies [33]. At P7, a model of hypoxia-ischemia in immature rats was used [42] with slight modifications as we already reported previously [33]. Briefly, animals passed through anesthesia with isoflurane (induction, $3.0 \%$; maintenance, $1.5 .0 \%$ ) and the left common carotid artery was double ligated and severed in rat pups of the vehicle and treated by steroids groups. The pups recovered for $1 \mathrm{~h}$ with their dams and then passed through hypoxia in the special humidified hypoxic in vivo chamber (CoyLab, Grass Lake, MI, USA). Hypoxia was produced by the decreasing concentrations of oxygen (from $11 \%$ to $8 \%$ ) balanced with nitrogen for 20 min, and then by $8 \%$ oxygen balanced with $92 \%$ nitrogen for another $35 \mathrm{~min}$ at $37^{\circ} \mathrm{C}$ as we previously reported [33]. Immediately after hypoxic ischemic insult rat pups were administered ip either vehicle or E4 alone or E4 combined with P4 and/or E2. The sham group was also anesthetized and operated but neither was exposed to HI operation nor injected. Rat pups were euthanized at P14 (Figure 6B).

\section{Measurement of rat pups rectal temperature}

To determine the possible effect of E4 treatment alone or E4 combined with other steroids on rat pups body and brain temperatures the measurement of the temperature per rectum was done with a multiple thermometer (BAT-10R) and a specific RET-4 probe (Bio Medical Instruments, Zollnitz, Germany) after hypoxic insult at 0,2 , and $4 \mathrm{~h}$ time points as described previously [33]. The variability of the rectal/body temperature was kept at low level by making the temperature measurements in a $25 \mathrm{C}^{\circ}$ room [37]. It is well-known that the rectal temperature correlates positively with the brain temperature $[100,101]$. The association between increased temperature and death or disability has at least 3 equally plausible explanations; brain injury raises body temperature, raised body temperature results in extension of the brain injury, or raised temperature is a marker for a process of which a part is encephalopathy [52].

\section{Brain and blood samples preparation}

The pups were sacrificed at P14. Preparation of the brain and blood samples were performed according to our protocol already used previously [33]. Briefly, animals were deeply anesthetized. Blood serum samples were prepared and stored at $-80 \mathrm{C}^{\circ}$. Transcardial perfusion of animals was performed with $0.9 \%$ saline solution followed by the perfusion of the 4\% paraformaldehyde in PBS at 4 $\mathrm{C}^{\circ}$. The brains, after being quickly removed, were weighed and fixed for $24 \mathrm{~h}$, followed by embedment in paraffin.

\section{The rat pups weight measurement}

The rat pups postoperative well-being was monitored in pretreated (neuroprotective model) and treated (therapeutic model) groups. Body weights were measured from P7 to P14.

\section{Hematoxylin-eosin staining}

Paraffin embedded brain samples were sliced into $5 \mu \mathrm{m}$-thick coronal sections at the hippocampus level [102]. Sections were deparaffinized and rehydrated and hematoxylin and eosin staining was performed. 


\section{Intact cell number per visual field}

Intact cell number was evaluated on 10 hematoxylineosin stained brain sections from each group. Counting was performed at magnification of 400x in 3 different fields of the respective brain areas in the cortex and different hippocampal regions: dentate gyrus (DG), subgranular zone (SGZ), cornu ammonis (CA1, CA2/ CA3). The sections were analyzed as described in our previous study [33].

\section{MAP-2 staining}

MAP-2 staining was performed on pups' coronal brain sections according to the protocol previously published [33]. Briefly, after antigen retrieval with citrate buffer, endogenous peroxidase activity was blocked, followed by second blocking and incubation with MAP2 at a dilution of 1:1000 (mouse monoclonal antibody; Sigma, St. Louis, MI, USA). Biotinylated goat antimouse immunoglobulin $\mathrm{G}$ (Vector, Burlingame, CA, USA) addition was followed by the antibody detection by using the avidin-biotin complex method (Vector), with 3,3-diaminobenzidine (DAB).

The infarct area corresponds to a loss of MAP-2 staining. 10 samples from each study group of both study designs were analyzed as in our previous study [33]. The ratio of the MAP-2 positive area in sham operated animals was considered as 1.0 by default.

\section{Doublecortin and vascular endothelial growth factor double immunofluorostaining}

To determine the effect of E4 alone or E4 combined with other steroids on neuro- and vasculogenesis in different regions of the hippocampus and the cortex, marker for neurogenesis doublecortin (DCX) and marker for angiogenesis-vascular endothelial growth factor (VEGF) were used as in previously published protocol [33]. Briefly, the sections proceeded through antigen retrieval step with citrate buffer and then endogenous peroxidase activity was blocked, followed by second blocking with normal goat serum and incubation with DCX 1:1000, and VEGF 1:100 (rabbit polyclonal antibody; Abcam, Cambridge, UK and mouse monoclonal antibody; Abcam, Cambridge, UK respectively) overnight. Alexa fluor goat anti-rabbit 1:1000 and Alexa fluor goat anti-mouse 1:1000 (Invitrogen Inc., Life technologies; Gent, Belgium) were used as secondary antibodies. The sections were incubated and mounted with DAPI containing medium (Vector, Burlingame, CA, USA). 10 samples from each study group were analyzed as already described in our previous study [33]. The percentage of positively stained DCX and VEGF cells was calculated.

\section{ELISA to detect blood serum glial fibrillary acidic protein (GFAP) (brain damage marker)}

ELISA for serum GFAP (USCNK Lifesciences Inc., China) was performed according to the manufacturers' recommendations.

\section{Statistical analysis}

For statistical analysis was used the Statview statistics package (Abacus Concepts, Inc., Berkeley, CA, USA). For statistical comparisons was used ANOVA followed by Fisher's PLSD, Scheffe's and Bonferroni/ Dunn post-hoc tests with $\mathrm{P} \leq 0.05$ considered as significant. All values are expressed as mean \pm SEM.

\section{ACKNOWLEDGMENTS}

The authors thank Mrs. Isabelle Dasoul for her technical help.

\section{CONFLICTS OF INTEREST}

Prof. JM Foidart is extraordinary professor at the University of Liege and Senior Scientific officer of Mithra Pharmaceuticals Inc (Belgium).

\section{GRANT SUPPORT}

This research was supported by grants from the Fonds de la Recherche Scientifique - FNRS (F.R.S. FNRS, Belgium): FRSM 3.4557.12, FRSM 3.4526.12, FRSM 3.4567.11, PDR T.0091.14, the Fonds spéciaux de la Recherche (University of Liege, Belgium): FSRC-12/64, FSRC-12/92, FSRC-14/89, FSRC-14/65, FSRC-14/109, FSRC-14/62, the Fonds Léon Fredericq (University of Liege, Belgium), the Direction Générale Opérationnelle de l'Economie, de l'Emploi et de la Recherche from the Service Public de Wallonie (SPW, Belgium): WB Health project No. 1318051, WB Health project No. 1318039, WB Health project No. 1318030, WB Health project No. 1318071,WB Health project No. 1318023, the Interuniversity Attraction Poles ProgrammeBelgian Science Policy (Brussels, Belgium): IAP Phase VII - P7/03, and the Actions de Recherche Concertées (University of Liege, Belgium): A.R.C. 11/16-02. 


\section{REFERENCES}

1. Martinez-Biarge M, Diez-Sebastian J, Wusthoff CJ, Mercuri E, Cowan FM. Antepartum and intrapartum factors preceding neonatal hypoxic-ischemic encephalopathy. Pediatrics. 2013; 132 (4):e952-9. doi: 10.1542/peds.20130511 .

2. Ferriero DM. Neonatal brain injury. N Engl J Med. 2004; 351(19):1985-95. doi: 10.1056/NEJMra041996

3. Grow J, Barks JD. Pathogenesis of hypoxic-ischemic cerebral injury in the term infant: current concepts. Clin Perinatol. 2002; 29(4):585-602. doi: 10.1016/S00955108(02)00059-3

4. Capani F, Saraceno GE, Botti V, Aon-Bertolino L, de Oliveira DM, Barreto G, Galeano P, Giraldez-Alvarez LD, Coirini H. Protein ubiquitination in postsynaptic densities after hypoxia in rat neostriatum is blocked by hypothermia. Exp Neurol. 2009; 219, 404-413. doi: 10.1016/j. expneurol.2009.06.007

5. Ankarcrona M, Dypbukt JM, Bonfoco E, Zhivotovsky B, Orrenius S, Lipton SA, Nicotera P. Glutamate-induced neuronal death: a succession of necrosis or apoptosis depending on mitochondrial function. Neuron. 1995; 15(4):961-73. doi:10.1016/0896-6273(95)90186-8

6. Volpe JJ. Perinatal brain injury: from pathogenesis to neuroprotection. Ment Retard Dev Disabil Res Rev. 2001; 7(1):56-64. doi: 10.1016/S1474-4422(08)70294-1

7. Pacher P, Beckman JS. Liaudet L. Nitric oxide and peroxynitrite in health and disease. Physiol Rev. 2007; 87(1):315-424. doi: 0.1152/physrev.00029.2006

8. Chang YC, Huang CC. Perinatal brain injury and regulation of transcription. Curr Opin Neurol. 2006; 19(2):141-7. doi:10.1097/01.wco.0000218229.73678.a8

9. Hagberg H, David Edwards A, Groenendaal F. Perinatal brain damage: The term infant. Neurobiol Dis 2015; pii: S0969-9961(15)30057-7. doi: 10.1016/j.nbd.2015.09.011

10. Gluckman PD, Wyatt JS, Azzopardi D, Ballard R, Edwards AD, Ferriero DM, Polin RA, Robertson CM, Thoresen M, Whitelaw A, Gunn AJ. Selective head cooling with mild systemic hypothermia after neonatal encephalopathy: multicenter randomised trial. Lancet. 2005; 65:663-70. doi:10.1016/S0140-6736(05)17946-X

11. Shankaran S, Laptook AR, Ehrenkranz RA, Tyson JE, McDonald SA, Donovan EF, Fanaroff AA, Poole WK, Wright LL, Higgins RD, Finer NN, Carlo WA, Duara $\mathrm{S}$, et al. Whole-body hypothermia for neonates with hypoxic-ischemic encephalopathy. N Engl J Med. 2005; 353(15):1574-84. doi: 10.1056/NEJMcps050929

12. van Kooij BJ, van Handel M, Nievelstein RA, Groenendaal F, Jongmans MJ, de Vries LS. Serial MRI and neurodevelopmental outcome in 9- to 10-year old children with neonatal encephalopathy. J Pediatr. 2010; 157 (221227), e222. doi: 10.1016/j.jpeds.2010.02.016.

13. Edwards DA, Azzopardi DV, Gunn AJ. 2013 Neonatal
Neural Rescue: A Clinical Guide. Cambridge University Press 2013.

14. Roof R, Duvdevani R, Braswell L, Stein D. Progesterone facilitates cognitive recovery and reduces secondary neuronal loss caused by cortical contusion injury in male rats. Exp Neurol. 1994; 129(1): 64-69. doi: 10.1006/ EXNR.1994.1147

15. Xu H, Gouras GK, Greenfield JP, Vincent B, Naslund J, Mazzarelli L, Fried G, Jovanovic JN, Seeger M, Relkin NR, Liao F, Checler F, Buxbaum JD, et al. Estrogen reduces neuronal generation of Alzheimer beta-amyloid peptides. Nat Med. 1998; 4, 447-451.

16. Roof R, Hoffman S, Stein D. Progesterone protects against lipid peroxidation following traumatic brain injury in rats. Mol Chem Neuropathol. 1997; 31(1): 1-11.). doi:10.1016/0006-8993(93à91526-X

17. Roof R, Hall E. Gender differences in acute CNS trauma and stroke: neuroprotective effects of estrogen and progesterone. J Neurotrauma. 2000; 17(5): 367-388. doi:10.1089/neu.2000.17.367.

18. Garcia-Segura LM, Azcoitia I, DonCarlos LL. Neuroprotection by estradiol. Prog Neurobiol. 2001; 63, 29-60. doi: 10.1016/S0301-0082(00)00025-3

19. Stein D. Brain damage, sex hormones and recovery: a new role for progesterone and estrogen?" Trends Neurosci. 2001; 24(7): 386-391. doi:10.106/S0166-2236(00à01821-X

20. Cho JJ, Iannucci FA, Fraile M, Franco J, Alesius TN, Stefano GB. The role of the estrogen in neuroprotection: implications for neurodegenerative diseases. Neuro Endocrinol Lett. 2003; 24, 141-147.

21. Currie LJ, Harrison MB, Trugman JM, Bennett JP, Wooten JF. Postmenopausal estrogen use affects risk for Parkinson disease. Arch Neurol. 2004; 61, 886-888. doi:10.1001/ archneur.61.6.886

22. Brann DW, Dhandapani K, Wakade C, Mahesh VB, Khan MM. Neurotrophic and neuroprotective actions of estrogen: basic mechanisms and clinical implications. Steroids. 2007; 72, 381-405. doi: 10.106/j.steroids.2007.02.003

23. Gold SM, Voskuhl RR. Estrogen and testosterone therapies in multiple sclerosis. Prog Brain Res. 2009; 175, 239-251. doi: 10.1016/S0079-6123(09)17516-7

24. Suzuki S, Brown, Wise PM. Neuroprotective effects of estrogens following ischemic stroke. Front Neuroendocrinol. 2009; 30, 201-211; doi: 10.1016/j. yfrne.2009.04.007

25. Samantaray S, Matzelle DD, Ray SK, Banik NL. Physiological low dose of estrogen-protected neurons in experimental spinal cord injury. Ann N Y Acad Sci. 2010; 1199, 86-89. doi: 10.1111/j.1749-6632.2009.05360.x.

26. Kaur P, Jodhka PK, Underwood WA, Bowles CA, de Fiebre NC, de Fiebre CM, Singh M. Progesterone increases brain-derived neurotrophic factor expression and protects against glutamate toxicity in a mitogen-activated protein kinase- and phosphoinositide-3 kinase-dependent manner 
in cerebral cortical explants. J Neurosci Res. 2007; 85, 2441-2449. doi: 10.1002/jnr.21370

27. Nilsen J, Brinton RD. Impact of progestins on estradiol potentiation of the glutamate calcium response. Neuroreport. 2002a; 13, 825-830. doi:10.1097/00001756200205070-00018

28. Nilsen J, Brinton RD. Impact of progestins on estrogeninduced neuroprotection: synergy by progesterone and 19-norprogesterone and antagonism by medroxyprogesterone acetate. Endocrinology. 2002b; 143, 205-212.

29. Nilsen J, Brinton RD. Divergent impact of progesterone and medroxyprogesterone acetate (Provera) on nuclear mitogenactivated protein kinase signaling. Proc Natl Acad Sci USA. 2003 ; 100, 10506-10511. doi: 10.1073/pnas. 1334098100

30. Goodman Y, Bruce AJ, Cheng B, Mattson MP. Estrogens attenuate and corticosterone exacerbates excitotoxicity, oxidative injury, and amyloid beta-peptide toxicity in hippocampal neurons. J Neurochem.1996; 66, 1836-1844. doi: 10.1046/j.1471-4159.1996.66051836.x

31. Singh M1, Su C. Progesterone and neuroprotection. Horm Behav. 2013; 63(2):284-90. doi: 10.1016/j. yhbeh.2012.06.003.

32. Holinka CF, Diczfalusy E, Coeling Bennink HJTC. Estetrol: A unique steroid in human pregnancy. J Steroid Biochem Mol Biol. 2008; 110:138-143. doi: 10.1016/j. jsbmb.2008.03.027.

33. Tskitishvili E, Nisolle M, Munaut C, Pequeux C, Gerard C, Noel A, Foidart JM. Estetrol attenuates neonatal hypoxicischemic brain injury. Exp Neurol. 2014; 261:298-307. doi: 10.1016/j.expneurol.2014.07.015.

34. Pluchino N, Santoro AN, Casarosa E, Giannini A, Genazzani A, Russo M, Russo N, Petignat P, Genazzani AR. Effect of estetrol administration on brain and serum allopregnanolone in intact and ovariectomized rats. J Steroid Biochem Mol Biol. 2014; 143:285-90. doi: 10.1016/j.jsbmb.2014.04.011.

35. Pluchino N, Drakopoulos P, Casarosa E, Freschi L, Petignat P, Yaron M, Genazzani AR. Effect of estetrol on BetaEndorphin level in female rats. Steroids. 2015; 95:104-10. doi: 10.1016/j.steroids.2015.01.003.

36. Abot A, Fontaine C, Buscato M, Solinhac R, Flouriot G, Fabre A, Drougard A, Rajan S, Laine M, Milon A, Muller I, Henrion D, Adlanmerini M, et al. The uterine and vascular actions of estetrol delineate a distinctive profile of estrogen receptor $\alpha$ modulation, uncoupling nuclear and membrane activation. EMBO Mol. Med. 2014; 6(10):1328-46. doi: 10.15252/emmm.201404112.

37. Feng Y, Fratkins JD, LeBlanc MH. Estrogen attenuates hypoxic-ischemic brain injury in neonatal rats. Eur J Pharmacol. 2005; 507(1-3):77-86. doi: 10.1016/j. ejphar.2004.11.039

38. Nuñez J, Yang Z, Jiang Y, Grandys T, Mark I, Levison SW. 17beta-estradiol protects the neonatal brain from hypoxia- ischemia. Exp Neurol. 2007; 208(2):269-76. doi: 10.106/j. expneurol.2007.08.020

39. Gerstner B, Lee J, DeSilva TM, Jensen FE, Volpe JJ, Rosenberg PA. 17Beta-estradiol protects against hypoxic/ ischemic white matter damage in the neonatal rat brain. $\mathrm{J}$ Neurisci Res. 2009; 87(9): 2078-86. doi: 10.1002/jnr.22023

40. Tsuji M1, Taguchi A, Ohshima M, Kasahara Y, Ikeda T. Progesterone and allopregnanolone exacerbate hypoxicischemic brain injury in immature rats. Exp Neurol. 2012; 233(1):214-20. doi: 10.1016/j.expneurol.2011.10.004

41. Li X, Zhang J, Chai S, Wang X. Progesterone alleviates hypoxic-ischemic brain injury via the Akt/GSK-3 $\beta$ signaling pathway. Exp Ther Med. 2014; 8(4):1241-1246. doi: $10.3892 /$ etm.2014.1858

42. Vanucci RC, Vanucci S. Perinatal Hypoxic-Ischemic Brain Damage: Evolution of an Animal Model. Dev Neurosci. 2005; 27(2-4):81-6. doi:10.1159/000085978

43. Trotter A, Steinmacher J, Kron M, Pohlandt F. Neurodevelopmental follow-up at five years corrected age of extremely low birth weight infants after postnatal replacement of $17 \beta$-estradiol and progesterone. J Clin Endocrinol Metab. 2012; 97(3):1041-7. doi: 10.1210/ jc.2011-2612

44. Lorenz L, Dang J, Misiak M, Tameh Abolfazl A., Beyer C, Kipp M. Combined 17beta-oestradiol and progesterone treatment prevents neuronal cell injury in cortical but not midbrain neurones or neuroblastoma cells. J Neuroendocrinol. 2009; 21, 841-849. doi: 10.1111/j.13652826.2009.01903.x

45. Mannella P, Sanchez AM, Giretti MS, Genazzani AR, Simoncini T. Oestrogen and progestins differently prevent glutamate toxicity in cortical neurons depending on prior hormonal exposure via the induction of neural nitric oxide synthase. Steroids. 2009; 74, 650-656. doi: 10.1016/j. steroids.2009.02.011

46. Aguirre CC, Baudry M. Progesterone reverses 17betaestradiol-mediated neuroprotection and BDNF induction in cultured hippocampal slices. Eur J Neurosci. 2009; 29, 447-454. doi: 10.1111/j.1460-9568.2008.06591.x

47. Aguirre C, Jayaraman A, Pike C, Baudry M. Progesterone inhibits estrogen-mediated neuroprotection against excitotoxicity by down-regulating estrogen receptor-beta. J Neurochem. 2010; 115, 1277-1287. doi: 10.1111/j.14714159.2010.07038.x

48. Carroll JC, Rosario ER, Pike CJ. Progesterone blocks estrogen neuroprotection from kainate in middle-aged female rats. Neurosci Lett. 2008; 445, 229-232. doi: 10.1016/j.neulet.2008.09.010

49. Jayaraman A, Pike CJ. Progesterone a ttenuates oestrogen neuroprotection via downregulation of oestrogen receptor expression in cultured neurones. J Neuroendocrinol. 2009 ; 21, 77-81. doi: 10.1111/j.1365-2826.2008.01801.x

50. Rosario ER, Ramsden M, Pike CJ. Progestins inhibit the neuroprotective effects of estrogen in rat hippocampus. 
Brain Res. 2006; 1099, 206-210. doi: 10.106/j. brainesres.2006.03.127

51. Yao J, Chen S, Cadenas E, Brinton RD. Estrogen protection against mitochondrial toxin-induced cell death in hippocampal neurons: antagonism by progesterone. Brain Res. 2011; 1379, 2-10. doi: 10.1016/j.brainres.2010.11.090

52. Laptook A, Tyson J, Shankaran S, McDonald S, Ehrenkranz R, Fanaroff A, Donovan E, Goldberg R, O'Shea TM, Higgins RD, Poole WK. National Institute of Child Health and Human Development Research Network. Neonatal Elevated temperature after hypoxicischemic encephalopathy: risk factor for adverse outcomes. Pediatrics. 2008; 122(3):491-9. doi: 10.1542/peds.20071673

53. Bystron I, Blakemore C, Rakic P. Development of the human cerebral cortex: Boulder Committee revisited. Nat Rev Neurosci. 2008; 9(2):110-22. doi: 10.1038/nrn2252

54. Nomura M, Korach KS, Pfaff DW, Ogawa S.E strogen receptor $\mathrm{b}(\mathrm{ERb})$ protein levels in neurons depend on estrogen receptor a (ERa) gene expression and on its ligand in a brain region-specific manner. Molec Brain Res. 2003; 110; 7-14. doi:10.1016/S0169-328X(02)0054-2

55. Hart SA, Patton JD, Woolley CS. Quantitative analysis of ER alpha and GAD colocalization in the hippocampus of the adult female rat. J Comp Neurol. 2001; 440: 144-155.

56. Shughrue PJ, Merchenthaler I.Evidence for novel estrogen binding sites in the rat hippocampus. Neuroscience. 2000; 99: 605-612. doi: 10.1016/S0306-4522(00)00242-6

57. O'Keefe JA, Li Y, Burgess LH, Handa RJ. Estrogen receptor mRNA alterations in the developing rat hippocampus. Brain Res Mol Brain Res. 1995; 30:115124. doi:10.1016/0169-328X(94)00284-L

58. Solum DT, Handa RJ. Localization of estrogen receptor alpha (ER-alpha) in pyramidal neurons of the developing rat hippocampus. Brain Res Dev Brain Res. 2001; 128:165175. doi: 10.1016/S0165-3806(01)00171-7

59. O'Keefe JA, Pedersen EB, Castro AJ, Handa RJ. The ontogeny of estrogen receptors in heterochronic hippocampal and neocortical transplants demonstrates an intrinsic developmental program. Brain Res Dev Brain Res. 1993 ; 75:105-12. doi: 10.1016/0165-3806(93)90069-M

60. Wagner CK, Pfau JL, De Vries GJ, Merchenthaler IJ. Sex differences in progesterone receptor immunoreactivity in neonatal mouse brain depend on estrogen receptor a expression. J Neurobiol. 2001; 47:176-82.

61. Dubal DB, Rau SW, Shughrue PJ, Zhu H, Yu J, Cashion AB, Suzuki S, Gerhold LM, Bottner MB, Dubal SB, Merchanthaler I, Kindy MS, Wise PM. Differential modulation of estrogen receptors (ERs) in ischemic brain injury: a role for ER \{alpha\} in estradiol-mediated protection against delayed cell death. Endocrinology. 2006; 147:3076-3084. doi:10.1210/en.2005-1177

62. Dubal DB, Zhu H, Yu J, Rau SW, Shughrue PJ, Merchenthaler I, Kindy MS, Wise PM. Estrogen receptor alpha, not beta, is a critical link in estradiol-mediated protection against brain injury. Proc Nat Acad Sci USA. 2001; 13;98(4):1952-7. doi: 10.1073/pnas.98.4.1952

63. Arevalo MA, Santos-Galindo M, Bellini M, Azcoitia I, Garcia-Segura LM. Actions of estrogens on glial cells: implications for neuroprotection. Biochim Biophys Acta. 2010; 1800, 1106-1112. doi: 10.1016/j.bbagen.2009

64. Dhandapani KM, Brann DW. Role of astrocytes in estrogenmediated neuroprotection. Exp Gerontol. 2007; 42, 70-75. doi: 10.1016/j.exger.2006.06.032

65. Vegeto E, Benedusi V, Maggi A. Estrogen antiinflammatory activity in brain: a therapeutic opportunity for menopause and neurodegenerative diseases. Front Neuroendocrinol. 2008; 29, 507-519. doi: 10.1016/j. yfrne.2008.04.001

66. Miñano A, Xifró X, Pérez, V Barneda-Zahonero B, Saura CA, Rodríguez-Alvarez J. Estradiol facilitates neurite maintenance by a Src/Ras/ERK signalling pathway. Mol Cell Neurosci. 2008 ; 39, 143-151. doi: 10.1016/j. men.2008.06.001

67. Prokai L, Prokai-Tatrai K, Perje'si P, Simpkins JW. Mechanistic Insights into the Direct Antioxidant Effects of Estrogens. Drug Dev Res. 2006; 66:118-125. doi: 10.1016/j.steroids.2007.10.011

68. Nilsen J, Brinton RD. Mitochondria as therapeutic targets of estrogen action in the central nervous system. Curr Drug Targets CNS Neurol Disorders. 2004; 3, 297-313. doi: $10.2174 / 1568007043337193$

69. Nilsen J, Chen S, Irwin RW, Iwamoto S, Brinton RD. Estrogen protects neuronal cells from amyloid beta-induced apoptosis via regulation of mitochondrial proteins and function. BMC Neurosci. 2006; 7- 74. doi: 10.1186/14712202-7-74

70. Nilsen J, Irwin RW, Gallaher TK, Brinton RD. Estradiol in vivo regulation of brain mitochondrial proteome. J Neurosci. 2007; 27, 14069-14077. doi: 10.1523/ JNEUROSCI.4391-07.2007

71. Brinton RD. The healthy cell bias of estrogen action: mitochondrial bioenergetics and neurological implications. Trends Neurosci. 2008a; 31, 529-537. doi: 10.1016/j. tins.2008.07.003

72. Irwin RW, Yao J, Hamilton RT, Cadenas E, Brinton RD, Nilsen J. Progesterone and estrogen regulate oxidative metabolism in brain mitochondria. Endocrinology. 2008; 149, 3167-3175. doi: 10.1210/en.2007-1227

73. Brinton RD. Estrogen regulation of glucose metabolism and mitochondrial function: therapeutic implications for prevention of Alzheimer's disease. Adv Drug Deliv Rev. 2008b; 60, 1504-1511. doi: 10.1016/j.addr.2008.06.003

74. Alkayed NJ, Murphy SJ, Traystman RJ, Hurn PD, Miller VM. Neuroprotective effects of female gonadal steroids in reproductively senescent female rats. Stroke. 2000; 31:161168. doi: 10.1161/01.STR.31.1.161 
75. Kuan CY, Roth KA, Flavell RA, Rakic P. Mechanisms of programmed cell death in the developing brain. Trends Neurosci. 2000; 23:291- 297. doi:10.1016/S01662236(00)01581-2

76. Zaidi AU, D'Sa-Eipper C, Brenner J, Kuida K, Zheng TS, Flavell RA, Rakic P, Roth KA. Bcl-X(L)-caspase-9 interactions in the developing nervous system: evidence for multiple death pathways. J Neurosci. 2001; 21:169- 175.

77. Wade CB, Dorsa DM. Estrogen activation of cyclic adenosine $5 \mathrm{Vmonophosphate} \mathrm{response} \mathrm{element-mediated}$ transcription requires the extracellularly regulated kinase/ mitogen-activated protein kinase pathway. Endocrinology. 2003; 144:832- 838. doi:10.1210/en.2002-220899

78. Gibson C, Constantin D, Prior M, Bath P, Murphy S. Progesterone suppresses the inflammatory response and nitric oxide synthase-2 expression following cerebral ischemia. Exp Neurol. 2005; 193: 522-530. doi:10.1016/j. expneurol.2005.01.009

79. Grossman K, Goss C, Stein D. Effects of progesterone on the inflammatory response to brain injury in the rat. Brain Res.2004; 1008: 29-39. doi:10.1016/j.branres.2004.02.022

80. Zhao Y, Wang J, Liu C, Jiang C, Zhao C, Zhu Z. Progesterone influences postischemic synaptogenesis in the CA1 region of the hippocampus in rats. Synapse. 2011; 65,880-891. doi: 10.1002/syn.20915

81. Gonzalez SL, Labombarda F, Gonzalez Deniselle MC, Mougel A, Guennoun R, Schumacher M, De Nicola AF. Progesterone neuroprotection in spinal cord trauma involves up-regulation of brain-derived neurotrophic factor in motoneurons. J Steroid Biochem. 2005; 94(1-3): 143-149. doi: 10.1016/j.jsbmb.2005.01.016

82. Labombarda F, Gonzalez S, Gonzalez Deniselle M, Garay L, Guennoun R, Schumacher M, De Nicola AF. Progesterone increases the expression of myelin basic protein and the number of cells showing NG2 immunostaining in the lesioned spinal cord. J Neurotrauma. 2006; 23: 181-192. doi:10.1089/neu.2006.23.181

83. Pierson RC, Lyons AM, Greenfield LJ Jr. Gonadal steroids regulate GABAA receptor subunit mRNA expression in NT2-Neurons. Brain Res Mol Brain Res. 2005; 138:105115; doi:10.1016/j.molbrainres.2004.10.047

84. Mani SK. Signaling mechanisms in progesteroneneurotransmitter interactions. Neuroscience. 2006; 138:773-781. doi:10.1016/j. neuroscience.2005.07.034

85. Pettus EH, Wright DW, Stein DG, Hoffman SW. Progesterone treatment inhibits the inflammatory agents that accompany traumatic brain injury. Brain Res. 2005; 049:112-119. doi:10.1016/j.brainres.2005.05.004

86. Quadros PS, Pfau JL, Wagner CK. Distribution of progesterone receptor immunoreactivity in the fetal and neonatal rat forebrain. J Comp Neurol. 2007; 504:42-56. doi: $10.1002 /$ cne. 21427

87. Jahagirdar $\mathrm{V}$, Wagner $\mathrm{C} \mathrm{K}$. Ontogeny of progesterone receptor expression in the subplate of fetal and neonatal rat cortex. Cereb Cortex. 2010; 20(5), 1046-52. doi: 10.1093/ cercor/bhp 165

88. Gérard C, Blacher S, Communal L, Courtin A, Tskitishvili E, Mestdagt M, Munaut C, Noel A, Gompel A, Péqueux $\mathrm{C}$, Foidart JM. Estetrol is a weak estrogen antagonizing estradiol-dependent mammary gland proliferation. J Endocrinol. 2015; 224(1):85-95). doi: 10.1530/JOE-140549

89. Murphy DD, Segal M. Progesterone prevents estradiolinduced dendritic spine formation in cultured hippocampal neurons. Neuroendocrinology. 2000; 72, 133-143. doi: $10.1159 / 000054580$

90. McEwen BS, Woolley CS. Estradiol and progesterone regulate neuronal structure and synaptic connectivity in adult as well as developing brain. Exp Gerontol. 1994; 29, 431-436.

91. Woolley CS, McEwen BS. Roles of estradiol and progesterone in regulation of hippocampal dendritic spine density during the estrous cycle in the rat. J Comp Neurol. 1993; 336, 293-306. doi: 10.1002/cne.903360210

92. Jin K, Zhu Y, Sun Y, Mao XO, Xie L, Greenberg DA. Vascular endothelial growth factor (VEGF) stimulates neurogenesis in vitro and in vivo. Proc Natl Acad Sci USA. 2002; 99(18):11946-50. doi: 10.1073/pnas.182296499

93. Zhu Y, Jin $\mathrm{K}$, Mao XO, Greenberg DA. Vascular endothelial growth factor promotes proliferation of cortical neuron precursors by regulating E2F expression. FASEB J. 2003; 17(2):186-93.

94. Ogunshola OO, Stewart WB, Mihalcik V, Solli T, Madri JA, Ment LR. Neuronal VEGF expression correlates with angiogenesis in postnatal developing rat brain. Brain Res Dev Brain Res. 2000; 119(1):139-53. doi:10.1016/S01653806(99)00125-X

95. Ennen CS, Huisman TA, Savage WJ, Northington FJ, Jennings JM, Everett AD, Graham EM. Glial fibrillary acidic protein as a biomarker for neonatal hypoxic-ischemic encephalopathy treated with whole-body cooling. Am J Obstet Gynecol. 2011; 205(3):251.e1-7. doi: 10.1016/j. ajog.2011.06.025

96. Massaro AN, Jeromin A, Kadom N, Vezina G, Hayes RL, Wang KK, Streeter J, Johnston MV. Serum Biomarkers of MRI Brain Injury in Neonatal Hypoxic Ischemic Encephalopathy Treated With Whole-Body Hypothermia: A Pilot Study. Pediatr Crit Care Med. 2013; 14(3):310-7. doi: 10.1097/PCC.0b013e3182720642

97. Mawet M, Maillard C, Klipping C, Zimmerman Y, Foidart JM, Coelingh Bennink HJ. Unique effects on hepatic function, lipid metabolism, bone and growth endocrine parameters of estetrol in combined oral contraceptives. Eur 
J Contracept Reprod Health Care. 2015; 20(6):463-75. doi: 10.3109/13625187.2015.1068934

98. Kaech S, Banker G. Culuring hippocampal neurons. Nat Protoc. 2006; 1(5):2406-15. doi:10.1038/nprot.2006.356

99. Beaudoin GM 3rd, Lee SH, Singh D, Yuan Y, Ng YG, Reichardt LF, Arikkath J. Culturing pyramidal neurons from the early postnatal mouse hippocampus and cortex. Nat Protoc. 2012; 7(9):1741-54. doi: 10.1038/nprot.2012.099

100. Thoresen M, Bagenholm R, Loberg EM, Apricena F, Kjellmer I. Posthypoxic cooling of neonatal rats provides protection against brain injury. Arch Dis Child Fetal Neonatal Ed. 1996; 74, F3-F9.
101. Yager J, Towfighi J, Vannucci R.C. Influence of mild hypothermia on hypoxic-ischemic brain damage in the immature rat. Pediatr Res. 1993; 34, 525- 29. doi:10.1203/00006450-199310000-00029

102. Paxinos G, Watson C. The rat brain in stereotaxic coordinates, 6th edition, 2007, Published by Elsevier Inc. 